Portland State University

PDXScholar

\title{
La chanson d'Yde et Olive: A Parable of a Medieval Self-Made Man
}

Noémie Young-Studer

Portland State University

Follow this and additional works at: https://pdxscholar.library.pdx.edu/open_access_etds

Part of the European Languages and Societies Commons, and the French and Francophone Literature Commons

Let us know how access to this document benefits you.

\section{Recommended Citation}

Young-Studer, Noémie, "La chanson d'Yde et Olive: A Parable of a Medieval Self-Made Man" (2003). Dissertations and Theses. Paper 4668.

https://doi.org/10.15760/etd.6552

This Thesis is brought to you for free and open access. It has been accepted for inclusion in Dissertations and Theses by an authorized administrator of PDXScholar. Please contact us if we can make this document more accessible: pdxscholar@pdx.edu. 


\section{THESIS APPROVAL}

The abstract and thesis of Noémie Young-Studer for the Master of Arts in French were presented February 5, 2003, and accepted by the thesis committee and the department.

COMMITTEE APPROVALS:

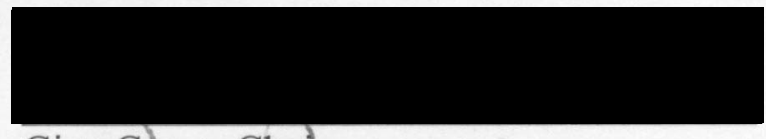

Gina Greco, Chà̀r

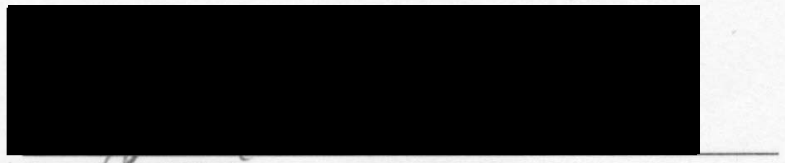

Stephen Walton

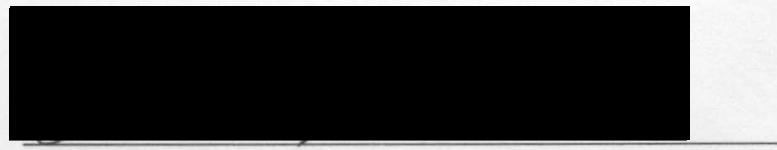

Christine Rose

Representative of the Office of Graduate Studies

DEPARTMENT APPROVAL:

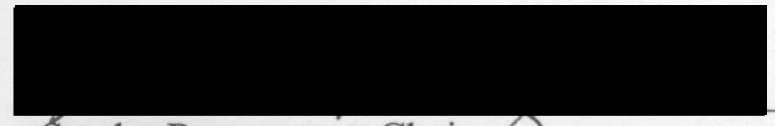

Sandra Rosengrant, Chair 0

Department of Foreign Languages and Literatures 
ABSTRACT

An abstract of the thesis of Noémie Young-Studer for the Master of Arts in French presented February 5, 2003.

Title: La chanson d'Yde et Olive: A Parable of a Medieval Self-Made Man

La chanson d'Yde et Olive, an early fourteenth-century epic poem from the Picard region, exemplifies the medieval custom of text renewal that seeks to adapt pagan materials to fit Christian doctrine. Largely based on the plot of the Ovidian fable Iphis and Ianthe from The Metamorphoses, its main character Yde undergoes a metaphorical transformation from a woman into a man. Moreover, much like the Ovide moralisé, a Christianized adaptation of the Latin original, Yde et Olive's message can be understood as a Christian parable for the purging of the sinful soul. To set up the poem's didactic message, the poet carefully infuses the story with contemporary social concerns, such as the theme of incest and gender disruption, both potentially offensive forces to the medieval social structure. In the backdrop of these threats to society, the heroine's overcoming of her struggles becomes all the more meaningful, leading to a clear moral message to the reader. While being a hybrid in genre and structure, the poem shows many borrowings from Christian hagiography, especially from the later, more romance-influenced versions of the Vitae of female transvestite saints. In these narratives, the heroine's spiritual 
development is typically portrayed in terms of "becoming male," which can also be understood as an erasure of sexual difference to approach God in a Neoplatonic sense. Moreover, the development of Yde's own hybrid state leading to the climax of revealing her new sex exemplifies medieval literary criticism, elaborating on the central theme of uncovering truth by exposing the hidden gem beneath the rough surface. 
LA CHANSON D'YDE ET OLIVE:

A PARABLE OF A MEDIEVAL SELF-MADE MAN

by

NOÉMIE YOUNG-STUDER

A thesis submitted in partial fulfillment of the requirements for the degree of

MASTER OF ARTS

in

FRENCH

Portland State University

2003 


\section{IN MEMORIAM \\ ELISABETH STUDER-EGLIN}

I would like to thank my parents who showed me the beauty of early music and art and my husband Brian for his love and support during my studies. Also special thanks to Prof. Gina Greco who introduced me to medieval literature and Prof. Christine Rose who initially pointed me to the existence of La Chanson d'Yde et Olive. The constant encouragements and help of the entire medieval faculty were invaluable during my time at Portland State University. 
INTRODUCTION: SITUATING THE POEM 1

The Huon de Bordeaux tradition .......................................................................... 1

Defining the genre of Yde et Olive ..................................................................... 4

CHAPTER ONE: YDE ET OLIVE AND THE OVIDE MORALISE 10

Medieval Hermeneutics 10

The tradition of translatio 13

Ovide moralisé: Christian doctrine in a Latin classic 18

CHAPTER TWO: THE HIDDEN DANGERS TO MEDIEVAL LINEAGE 23

The disruption of lineage 25

The ambiguous treatment of incest in medieval literature 30

Cross-dressing as disruption or protection of the family line? 35

CHAPTER THREE: YDE ET OLIVE IN THE TRADITION OF HAGIOGRAPHY 40

The concept of male and female 41

The tradition of hagiography and the phenomenon of transvestite saints 44 Parallels of basic structure between the Vitae and Yde et Olive.... 48 
The wider significance of transformation in Yde et Olive ................................ 58

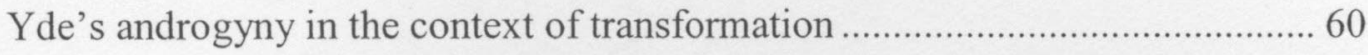

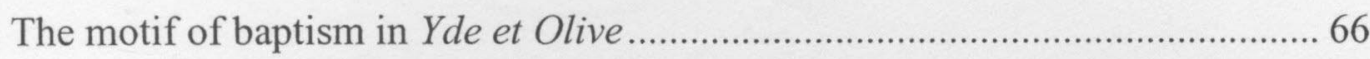

CONCLUSIONS: GENDER PLAY IN MEDIEVAL CROSS-DRESSING .......... 72

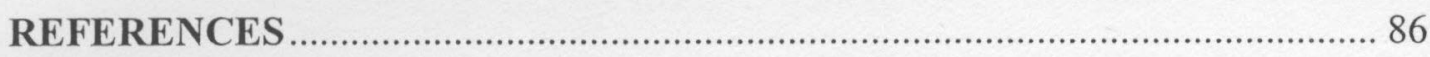

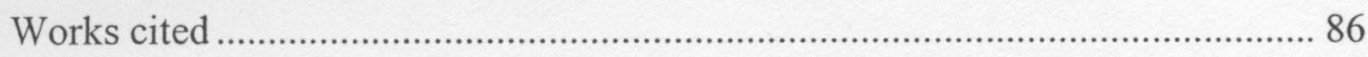

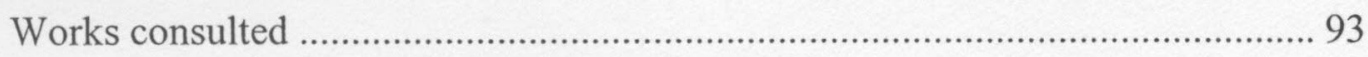

APPENDIX: THE SONG OF YDE AND OLIVE ............................................ 96 


\section{PREFACE}

The fourteenth-century epic poem La Chanson d'Yde et Olive stands as a typical example of medieval text production in the tradition of translatio. Following the custom of glossing ancient texts, its story line clearly shows borrowings from Ovid's Iphis and Ianthe, as the central figure is transformed metaphorically from a woman into a man. The poem also shows many borrowings from early Christian hagiography, especially from the later, more romance-influenced versions of the Vitae of female transvestite saints as it describes the heroine's coming-of-age in terms of changing from fe-male into male in a religious sense. Much like the Ovide moralisé, a fourteenth-century reworking of Ovid's fables, the poem uses the theme of cross-gender transformation as a parable for spiritual growth and purification of the soul. A hybrid in genre, Yde et Olive stands as a typical example of medieval literary practice that sought to appropriate pagan materials to fit Christian doctrine. Moreover, with the heroine being a hybrid herself, its central theme of transformation and its climax in the revelation of the heroine's new male gender, the poem exemplifies the medieval obsession with uncovering truth in text.

The introductory chapter of this study will serve as an initial orientation point, placing the poem within the epic cycle of Huon de Bordeaux, from which it is taken, as well as trying to define its genre, a mix between the chanson and the romance. Its subject matter and major motifs are shown to be inspired from folk literature. They reappear in several other works from the period, among which Le 
Roman de Silence will be of great interest for the study due to its parallels to Yde et Olive. Above all, in relation to its basic plot, the Ovidian myth Iphis and Ianthe will be considered the primary source, not only for Yde et Olive, but also for Silence.

Chapter one places the poem in the context of translatio by relating it to the Ovide moralisé, a fourteenth-century version of the Ovidian fables. To explain more clearly its connection to the ancient source, I will begin by discussing medieval hermeneutics, firmly based on Scriptural exegesis, or the uncovering of truth. With Dante in the high Middle Ages, the idea of polysemy in text becomes embedded in secular text production, as becomes already evident with earlier authors like Marie de France, who alludes in her fables to the hidden meanings "inside the shell" of the narrative. In the tradition of translatio, ancient sources serve as a base upon which medieval concerns are superimposed, following the teachings of St. Augustine of "taking the gold out of Egypt." Marie's work emphasizes the task of the author to gloss the Classic source, to add a "surplus" to its depth and meaning. Similar thoughts can be found in Chrétien's prologues that emphasize the didactic role of his narratives. In taking the intellectual heritage that came from Greece and Rome, translatio transforms ancient fables into religious parables. The Ovide moralisé and Yde et Olive come from that same literary tradition as both texts take the ancient source and infuse it with a Christian moral message.

In order for a parable to work well, the author has to prepare the grounds upon which he can build his lesson, or in Chrétien's words, the "grains must be put upon fertile soil." Chapter two then shows how the Yde et Olive poet is setting up 
the grounds for a good "harvest" by introducing the theme of danger and threat in the plot. The poet encodes his narrative with contemporary concerns, such as the theme of incest and gender disruption, both symbols for threats to the social fabric of the time. These motives pose obvious dangers to the "straightness" of lineage. Le Roman de Silence and Yde et Olive play with the theme of social disruption, a disruption that in both cases is caused by the father figure. In Yde's case, the theme of incest plays an important role, especially when seen in the context of the contemporary attitude towards this particular incursion against the natural order. A comparison to the typical treatment of the incest theme in medieval texts gives valuable insight into the ambiguous persona of Yde who acts as a daughter in penance for her father's sins, as well as the typical saintly hero. By disguising herself as a man, Yde does not disrupt the normal societal order, but instead brings back order to the family line by saving the kingdom of her father and uniting it with Rome. Yde does not cross-dress to challenge nature, but to bring everything back into its natural balance. In Silence as well as Yde et Olive, cross-dressing is not used to "trick" somebody or to exert power, as would be typical for the fabliaux, but to elevate the heroine's status in a moral sense.

In Yde's case, this elevation has yet another component, as she is actually transformed into a man at the end. Chapter three looks at the theme of transformation in the context of hagiography and interprets Yde's becoming a man as ascension from the "female body" to the "male soul." It starts out by discussing the medieval concept of male and female in general, based on a certain linearity of 
thought that equals exterior signs with interior values and Aristotle's concept of an evolving universe. As religious texts show, the concept of "becoming male" is used as a metaphor to symbolize a woman's spiritual growth. Christian medieval hagiography takes this concept and creates an entire corpus of literature around that theme: the Vitae of transvestite saints, that tell the stories of pious women who choose to become male to be closer to God. Chapter three will show the parallels between Yde et Olive and this hagiographic tradition: not only the basic three-part structure of flight-disguise-revelation, but also several distinct motifs are used in both, such as the temptation of evil and the threat to the virgin body, typically through incest or other "perverted" sexual relations. Moreover, the focus on corporality is typical when describing female sanctity; that is, the female body always remains a barrier to fully approach God, a barrier that Yde will overcome in becoming fully male. The transformation of that female body in Yde's case should also be seen in the backdrop of a religion that uses transformation as the center stone of its faith, such as in the miracle of the Eucharist or the transforming power of baptism. In connection with baptism, the theme of androgyny becomes important, as Yde's persona remains ambiguous throughout the entire narrative, always hovering between male and female. In line with her transformation to male as spiritual ascension, her androgyny can be interpreted as an erasure of sexual difference and approach to God in a Neoplatonic sense. Moreover, the theme of androgyny and erasure of difference is certainly one of the main recurring discussion points in literary criticism up into the twentieth century. This erasure of sexual difference in 
medieval times is equaled with "becoming male." Yde's development towards maleness is accompanied with several "baths," bringing us back to the motif of baptism. Seen against early Christian baptismal rites, Yde's story can be traced according to the consecutive steps of instruction, apostaxis, syntaxis, disrobing, immersion, anointing and robing. Seen in the light of baptism, which always brings about a purging of sins, Yde et Olive takes on the same basic message as the Ovide moralisé, interpreting the story of Iphis and Ianthe as a purification of the sinful soul. It is in that light that Yde et Olive becomes a Christian parable based on an ancient Classic in the tradition of translatio.

The conclusive chapter will try to put Yde et Olive in the context of other medieval literature that uses the motif of cross-dressing in different ways and with that, it will touch on sociological issues raised in the text in relation to Judith Butler's theory on gender performance. Maybe the most confusing passage of the poem, the one about Yde and Olive's wedding night which happens before her transformation as a man, stands as a good example of how writers allow an ambiguous space when discussing gender, a tendency that is particularly strong in thirteenth-century France. While this last chapter does not directly contribute to the main thesis of the study, it will help to place Yde et Olive in a wider context. 
INTRODUCTION: SITUATING THE POEM

\section{The Huon de Bordeaux tradition}

La chanson d'Yde et Olive (Yde et Olive) is one of six sequels to an epic poem called Huon de Bordeaux, preserved in a single copy in the Turin MS L.II.14, dated 1311. Although the sequels form an entire cycle of poems centered around the main hero Huon and his descendants, the focus of this study will limit itself to Yde et Olive as an individual text, as its narrative seems only marginally dependent on its bigger context. The Huon manuscript tradition as a whole contains many other renditions beside the Turin sequels, and Yde et Olive appears in the fourteenthcentury Cangé manuscript on its own, in a dramatic adaptation under the name of Miracle de la fille d'un roy, as part of a set of Marian plays called Miracles de Notre Dame par personnages. The entire Huon cycle reappears in a fifteenth-century prose version called Les prouesses et faictz merveilleux du noble Huon de Bordeaux, probably written for Charles VII in 1454, which was then translated into Middle English in the sixteenth-century and published under the name The Boke of Duke Huon of Bordeaux. This sixteenth-century prose text remains the only published version of the narrative in English to this day. To my knowledge, the original Old 
French text in verse form as it appears in the Turin manuscript has never been translated. ${ }^{1}$

As mentioned, Yde et Olive can be understood as an individual text. However, as it appears as the third sequel in the cycle, it might be helpful to situate the poem in the entire Huon context first, without going too much into the actual narrative, as it exceeds the focus of this study. ${ }^{2}$ The first sequel Esclarmonde starts out by placing the main character Huon in a supernatural context: Auberon, son of Morgan the fairy, wants to make him heir to Monmur. In medieval fashion, Huon has to overcome a series of obstacles first, of which protecting his wife Esclarmonde and daughter Clarisse remains the main impetus. Although the hero has to undergo great hardship during his quest, supernatural signs accompany him all the way, thus never leaving any doubt that his lineage has the privilege of divine protection. Back in Monmur, Huon is first forced to fight Arthur who contests his inheritance. Huon's wife is granted fairy powers with Christ's assistance before both Huon and Esclarmonde are crowned king and queen of Monmur.

The second sequel Clarisse et Florent narrates the adventures of Huon's daughter Clarisse, which include cross-dressing as a man and successfully engaging in battle against her adversaries, two elements which will reappear in the following

\footnotetext{
${ }^{1}$ For study purposes, I undertook my own English translation of the sequel Yde et Olive, a translation that is by no means elegant but should serve merely as a reference point for the discussion of the poem and is therefore included in Appendix A following this essay. Barbara Anne Brewka's unpublished Old French edition, as it appears in her 1977 Dissertation from Vanderbilt University served as a base for this translation.

${ }^{2}$ The following brief synopsis is based on a lengthy summary in Brewka's dissertation, which contains all six sequels.
} 
sequel Yde et Olive. Garin, king of Aragon, acts as the main obstacle to Clarisse's happiness as he refuses to allow his son Florent to marry Clarisse because she hides her noble lineage from them. Florent and Clarisse are then propelled into a series of adventures, while Aragon engages in combat against the Lombards due to an old family feud with Florent's uncle Desiier de Pavia. Huon reappears at this point to reconcile both sides and to reveal Clarisse's identity, which brings peace and stability to Aragon. This is the point of departure for Yde et Olive, subject of the present study.

The heroine Yde in Yde et Olive undergoes a similar fate as her mother Clarisse but the poem elaborates on the theme of cross-dressing. The narrative starts with Clarisse's death at childbirth. Grieved by his loss, Florent, king of Aragon, falls in love with his own daughter Yde due to her resemblance to his late wife. When he announces his intentions to marry his daughter, Yde is deeply scared of God's punishment for such a heretical sin. She escapes the threat of incest by crossdressing as a man and fleeing the palace on her father's warhorse, which pushes her into in a series of adventures similar to her mother's, including fighting thirty thieves and escaping a Spanish army. Placing her fate into God's hands, she acts under divine protection just as her grandfather Huon did. Her final destination is Rome where she intends to warn King Oton of an impending invasion by the Germans, a bit of information that she picked up during her travels. Still disguised as a man, she is engaged into feudal service by King Oton whom she serves with great valor. In the following year, she fights off the Spanish king who attacks the Roman kingdom 
because Oton refused to allow him to marry his daughter Olive. In the meantime, beautiful Olive is falling in love with Yde because of her (his) prowess, and when Yde liberates the entire kingdom, Oton wants to give her (him) his daughter in marriage as a reward. Deeply troubled, Yde accepts and places her trust in God. During the wedding night, Yde feigns an illness, but after two weeks, she has to confess her identity to Olive, who stands by her and promises to keep it a secret. However, a servant overhears their conversation and denounces them to the king who forces Yde to take a bath with him to prove her (his) identity. Just when the king's counselors advise him to burn Yde and Olive, an angel descends from Heaven and transforms Yde into a real man. The angel predicts Oton's death and the birth of Croissant, son of Yde and Olive.

Although the cycle continues, the following sequels will not contribute anything important to the present focus. The sequels are called Croissant, which tells the story of Yde's son who loses his kingdom to Desiier de Pavia's family (see Clarisse et Florent), but ultimately regains his reign, Yde and Olive II, in which Desiier takes control of Aragon but with Huon's intervention, repents at the end, and Huon et les Géants which ends with a summary of all previous episodes and with Esclarmonde giving birth to a son to secure the family line.

\section{Defining the genre of Yde et Olive}

Before looking at specific aspects of the poem, a general description of all major influences might be helpful to place Yde et Olive in its literary context. Clark 
characterizes Yde et Olive as late epic or chanson d'aventure, a genre which resembles greatly the chanson de geste in its formal character, but deals with subject matters that are atypical for the earlier epic genre, such as love intrigues, kidnappings, sea voyages and disguise of the main character (90), all aspects that are found in the Huon de Bordeaux cycle. In a way, Yde et Olive can be considered as a text that stands between the chanson and the romance genre. Many motifs in it are borrowed from the chanson de geste, such as the recurring image of the war horse, sign of prowess and nobility:

Vient a l'estable, au destrier est lancie, / Puis est montee, que ne s'atarga mie. / Par nului n'est veüe ne coisie. / Fors d'Arragonne en van. Dix li aïe! (She comes to the stable, dashes to the war horse, / Then she mounts, for she does not tarry. / By no one she is seen nor recognized. / She goes out of Aragon. May God help her!)(v. $6564-6567)^{3}$

Moreover, the hero's guidance by God is underlined with the traditional prayer before battle, typically found in chansons:

Ydes venoit a bataille rengie; / Diu reclama, le fil sainte Marie / En .j. vert elme ot sa ciere emb[r]oncie / Et ot se targe empres son pis sacie. (Yde came ready for battle; / She called upon God, the son of Holy Mary / She bent forward her face, in a green helmet. / And she pressed her shield against her chest.) (v. $6975-6978)$

\footnotetext{
${ }^{3}$ All translations are my own, based on Barbara Anne Brewka's edition of the poem, as found in: "Esclarmonde, Clarisse et Florent, Yde et Olive I, Croissant, Yde et Olive II, Huon et les Géants, sequels to Huon de Bordeaux, As Contained in Turin ms. L. II. 14: An Edition." Diss. Vanderbilt U, 1977.
} 
However, these typical chanson motifs are mixed with romance features as well. In both the chanson and the romance genre, the hero usually engages in some sort of adventure that forces him to leave his familiar environment, but a fundamental difference in focus separates the two genres:

The chansons de geste are seen as representations of a collective experience; their concern is with feudal and religious consensus, the role of the hero being to embody in his actions the ideals of the group he represents. Romances are seen as belonging to a historically later period. Their production, stimulated by the rise of courtliness, marks a new concern with interiority and the individual. (Kay 2)

In Yde et Olive, both aspects are present but in various degrees. Whereas the religious aspects in the poem play an important role, they are embedded in a plot that focuses primarily on the psychological development of the heroine, portraying Yde as typical romance heroine, or rather romance hero. In addition, the title starting with "la chanson de..." clearly evokes the chanson genre, but unlike typical epic poems from the period that designate a man's name in the title, the poem's title evolves around two women's names: La chanson d'Yde et Olive (Canadé-Sautman 202). It is these kinds of borrowings and disruptions from several genres that make the poem so hard to classify. De Weever states: "The title . . suggests an epic poem, but the work is more romance than epic" (371). Moreover, hagiography evolving gradually to resemble the romance genre represents yet another important 
influence that plays a central role in the poem and will take up a big part of the present discussion. ${ }^{4}$

Moving away from the more formal context to the subject matter of the poem, Yde et Olive represents a good example of how texts evolved around certain motifs, motifs that migrated with time and formed certain clusters within medieval literature (Canadé-Sautman 204). The motif of incest is clearly borrowed from folk literature. Folklorists have identified an entire corpus of literature evolving around the "lecherous father"- motif (Thompson 384) ${ }^{5}$ with the same basic plot:

... a king loses his wife in childbirth. The child, a daughter, grows to be a beautiful maiden, and her father determines to marry her because she is the very image of her dead mother. The reaction of the daughter is one of horror, and she successfully thwarts her father's designs. Her course of action varies from version to version, but the result is always the same: she embarks on a series of picaresque-style adventures. (Clark 90)

Philippe de Remy, sir de Beaumanoir's thirteenth-century romance La Manekine is maybe the best-known example, and many critics have underlined the resemblances between the two heroines in La Manekine and Yde et Olive, but it would exceed the focus of this study to compare the two texts in detail. Maybe most importantly, both heroines escape the threat of paternal incest, but Joïe of La Manekine mutilates herself to render her body undesirable. She also embarks on a series of adventures during which she will stay passive, having to go through several cycles of

\footnotetext{
${ }^{4}$ See chapter three.

${ }^{5}$ Motif T411.1 in vol. 5 .
} 
persecution. Although one could view Yde's cross-dressing as some sort of "mutilation" of her female body, thereby following the same motif, she gets entangled in a series of adventures in which she takes a very active part, fighting her way to Rome where she becomes a noble knight.

The motif of cross-dressing certainly reappears in numerous variations in medieval texts. However, narratives that focus entirely on a female protagonist who cross-dresses throughout the plot and succeeds in her new "role" so exceptionally well as in the present text are more difficult to find. For the present study, the thirteenth-century Roman de Silence by Heldris de Cornuälle will be of interest, especially in respect to the development of the heroine's psychology and in its underlying theme of lineage, as will be shown in chapter two. As far as female cross-dressers who undergo an actual biological sex change are concerned, these examples are even more rare to find in medieval literature, as Canadé-Sautman points out:

This motif actually appears in two chanson de geste from the first half of the fourteenth century that seem to originate in the same geographical and cultural area ${ }^{6}$ : Yde et Olive, followed by versions for the theater and later prose narratives, and Tristan de Nanteuil ... [T]heir version of the "manwoman" theme differs greatly from those texts in which the disguise and the behavioral change are a fleeting convenience and are rapidly brought back to female, strictly gendered identity. (200)

\footnotetext{
${ }^{6}$ The Yde et Olive poet has been identified as Picard. All texts in the Turin manuscript are connected to that same region.
} 
That is, whereas in other texts from the period, such as the fabliaux, cross-dressing is extensively used as some sort of trickery, in which the wife is usually portrayed as wanting to take advantage of her undesirable husband, cross-dressing in the present text is used in an entirely different manner, as will become evident in the course of this discussion. As far as the actual sex change is concerned, Canadé-Sautman adds that there seems to be a folklore motif labeled as "shift of sex" that bears resemblances with Yde's adventures and that is usually centered around Spain and Italy, again matching Yde's confrontation with the Spanish and her ultimate journey to Rome (209).

However, more importantly than all these minor influences, Ovid's Iphis and Ianthe from The Metamorphoses, ${ }^{7}$ a text that in the fourteenth century was mainly available in its "Christianized" version of the Ovide moralisé, serves as the main orientation point for $Y$ de et Olive, as chapter one will show.

${ }^{7}$ Although dealing with an entirely different focus, Durling's article "Rewriting Gender: Yde et Olive and Ovidian myth" triggered my initial interest in Ovid. 
CHAPTER ONE: YDE ET OLIVE AND THE OVIDE MORALISÉ

\section{Medieval hermeneutics}

Writings can be understood principally in four senses. The first is called the literal, and this is the sense that does not go beyond the surface of the letter, as in the fables of the poets. The next is called the allegorical, and this is the one that is hidden beneath the cloak of these fables, and is a truth hidden beneath a beautiful fiction ... The third sense is called moral, and this is the sense that teachers should seek to discover throughout the scriptures, for their own profit and that of their pupils ... The fourth sense is called anagogical, that is to say, beyond the senses; and this occurs when a scripture is expounded in a spiritual sense ...

Dante Alighieri, Il Convivio (40-1)

Before focusing on the actual analysis of the poem in chapters two and three, the present chapter will try to initially place Yde et Olive in the tradition of translatio by making a connection between the poem and the "renewed" Ovidian myth Iphis and Ianthe, as they both use the theme of gender transformation as a means to create a parable. The discussion about the relationship between Yde et Olive and the Ovide 
moralisé may be best introduced by first looking at literary practices of the time in general. Medieval literary criticism was firmly embedded in the tradition of scriptural hermeneutics. With the firm establishment of Christianity as the predominant doctrine, the Bible figured not only as the center stone of the Christian religion, but became also the central guidebook for the literary world. Eventually, interpretative techniques used in biblical exegesis determined how secular texts were read as well. These techniques were aimed at getting to the "inner truth" of every text, the hidden divine meaning that had to be revealed first. The focus on uncovering "truth" flavored all major literary discourses of the period. In describing the image of "the kernel and the husk," commonly used in literary criticism at the time, Miller quotes from a sixth-century text by Fulgentius:

Not uncommonly poetic songs are seen to be comparable with nuts. For as in a nut there are two parts, the shell and the kernel, so also there are two parts in poetic songs: the literal and the mystical senses. The kernel lies hidden beneath the shell; beneath the literal sense lies the mystic understanding. If you wish to have the kernel, you must break the shell ... (57)

At the advent of Christianity, Saint Augustine's De Doctrina Christiana already discusses extensively the problem of biblical interpretation, in a time when the Scriptures still consisted of many different fragments in Hebrew, Greek and Latin:

But the ambiguities of figurative words, which are now to be treated, require no little care and industry. For at the outset you must be very careful lest you 
take figurative expressions literally... There is a miserable servitude of the spirit in this habit of taking signs for things, so that one is not able to raise the eye of the mind above things that are corporal and created, to drink in eternal light. (in Miller 55)

With the Bible as the center stone of Christian faith, the interpretation of divine law developed into a tool to exert power, as Church fathers tried to establish the guidelines upon which official doctrine was to be built. In general, the preoccupation with textual interpretation extends throughout the entire medieval period, gradually moving from a primary focus on Scriptural texts to secular texts as well, as becomes evident in the High Middle Ages. The twelfth and thirteenth century figure as important milestones for the discussion of Yde et Olive, maybe most importantly due to Dante's motivation for applying biblical exegesis to nonsacred texts in a more explicit manner. In the Letter to Can Grande, he explains how his Divina Commedia is

... polysemous, that is, having several senses. For the first sense is that which is contained in the letter, while there is another which is contained in what is signified by the letter. The first is called literal, while the second is called allegorical, or moral, or anagogical. (in Leitch, et al. 251)

Consequently, the theme of "breaking the husk" to get to the inner truth shaped a vast number of secular texts as well. The examples are too numerous to list, but that of Marie de France may be particularly suited to illustrate the point. In her Fables, she often alludes to finding truth, such as in The Woman and her Hen, in which the 
author encourages the reader to decode the message in her fables. The Hen in the fable refuses to eat from a basket of grains, but prefers instead to look for her own food by scratching all over the ground:

Si devant mei estut une mine / Tuz jurs pleine, pas ne lerreie / Ne pur ceo ne targereie / Que jo ne quesisse tuz jurs plus - / Sulunc ma nature, sulunc mun us.

(And if there were in front of me / A basket always full of grain, / I'd not desist, I'd not refrain / From searching for yet more all day. / Such is my nature and my way). (257)

Marie insists on the reader's task to search for the truth independently instead of taking for granted what is laid before the audience. Of course, with Marie's work, one can always find a socially critical component to this idea of finding "truth" as well, which is of lesser concern for this study. However, the basic idea of a text containing hidden truths will be central to the present discussion, as the plot of Yde et Olive will be discussed as a parable.

\section{The tradition of translatio}

As previously mentioned, the poem is deeply inspired by the Ovide moralisé, an early fourteenth-century Christianized version of Ovid's work, as they both use the theme of cross-gender transformation in an allegorical sense. To better understand how the work of Ovid was "appropriated" to fit as a Christian model for the poem discussed in this study, it is important to look at what is commonly referred 
to as St. Augustine's theory of "Taking the Gold out of Egypt," a literary theory that permeated the Middle Ages since the fifth century. In a time when Christianity still needed to assert itself, proponents of Christian faith generally did not hold any esteem for pagan authors. However, Augustine asserted that even pagan texts held higher truths, truths that were hidden from their authors due to their ignorance and lack of true faith. In De Doctrina Christiana, the Church father explains that just as the people of Israel secretly took Egyptian gold with them to put it to a better use, ancient texts should be taken from the pagans "as from unjust possessors and converted to our use" (in Miller 54). Backed by theological arguments, the use and adaptation of classic literature figured as an important influence in medieval texts. For a modern reader, this kind of poetic creation might look questionable, but the Middle Ages had a different idea of authorial "ownership." The concept of authorship did not exist, as everything was viewed as given and created by God. As Burrows explains, "To make available the works of the great authors of the past, by compilation, translation, commentary, or even simple transcription was not an unworthy aim for a writer of that time" (33). Many authors used classical sources for their own literary productions. Consequently, many prologues of the period start by referring to an ancient source, such as the prologue of Cligès by Chrétien de Troyes that celebrates translatio, the transmission of intellectual property from Greece to France. Chrétien's prologue is crucial to this discussion because it weds the idea of linearity of translatio with the idea of linearity of lineage, which will be a central point of discussion in chapter two. In Cligès, Chrétien begins his narrative by 
outlining the Arthurian heritage of his hero and how he moved from Greece to Britanny: "Il était si preux et d'un coeur si brave que, pour conquérir prix et louange, il quitta la Grèce pour l'Angleterre qu'on appelait alors la Bretagne" (Poirion 173). After outlining this transmission of worldly power from Greece to France, the poet moves on to the question of intellectual power a few lines further down:

Par les livres en notre possession, nous connaissons les faits des Anciens et l'histoire du temps jadis. Nos livres nous ont appris qu'en Grèce régna d'abord le prestige de la chevalerie et de la culture. La chevalerie passa ensuite à Rome ainsi que la totalité de la culture, maintenant parvenue en France. Dieu veuille qu'elle s'y maintienne et que le séjour lui plaise assez pour que la gloire qui y a élu domicile ne quitte plus jamais la France! Dieu l'avait seulement prêtée aux autres: car des Grecs ni des Romains, il n'y a plus aucune nouvelle; leurs paroles ont cessé car leur vive braise est éteinte. (in Poirion 173)

Clearly, what constituted once the glory of Greece and Rome, now resided in France, as its high culture was transmitted in a linear fashion from its original source to the new world. However, while the transmission as such was looked at as linear, the Classic works themselves were by no means transmitted in a linear fashion; that is, they underwent quite a change during that transmission. In her Lais, Marie de France starts with the following prologue, again pointing to translatio, but adding yet another component to that thought: 
C'était la coutume des anciens, comme en témoigne Priscien de s'exprimer, dans les livres qu'ils écrivaient jadis, avec beaucoup d'obscurité en pensant aux generations à venir et à ceux qui devaient apprendre leurs écrits: ils leur laissaient la faculté de gloser la lettre et d'y apporter le surplus de leur intelligence. (31)

Poets did not simply take over the heritage of Greece and Rome, but they glossed it, adding the "surplus" of their own intellectual power. That surplus of the poet added to the classical text an important new component. It was a surplus that was shaped to fit the authorial intent, a surplus that could "bend" ever so slightly the ancient text to fit the present purpose. Marie was a master in bending or adapting her "sources," as can be seen in her Fables that are skillfully altered from their original version by Aesop to make the reader think twice about their "truth." Again, whereas in Marie's case this technique figured as a means to comment mainly on social issues of the times, other writers used ancient authority to assert religious truths. In either case, the aim was a didactic one; that is, to teach a lesson through "fable." Chrétien's prologue to Perceval serves well to illustrate this point:

Qui sème peu récolte peu, mais qui veut s'assurer une bonne récolte doit répandre les grains sur une terre qui lui procure un rendement cent fois supérieur. Car dans une terre sans valeur la bonne graine se dessèche et meurt. Chrétien sème et jette la graine d'un roman qu'il commence, et il sème en une si bonne terre qu'il ne peut manquer d'en retirer grand profit. (in Poirion 685) 
Chrétien clearly announces that his romance is not merely a fable, but serves as a parable to illustrate a higher truth, a parable that will fall onto fertile ground, that will have a positive effect on the reader who will draw a lesson from it. Marie and Chrétien's examples show well how with the tradition of translatio, the Middle Ages seem to have almost rewritten an entire corpus of literature by taking existing texts and by glossing them; that is, by adding commentary to the texts that often established guidelines for how a particular text had to be read and understood. Freeman points to this adding or glossing of materials by calling translatio the tradition of "text renewal"(159).

In more extreme cases of doctrinal writings, it seems that in claiming to discover the "inner truth" and to break away "the shell" of these ancient texts, poets often hid and buried the texts under layers of commentary, which really did the opposite. As Blumenfeld-Kosinski describes: "The texts a twelfth-century clerk would have encountered were not in their "pure" state but were already encrusted with many layers of commentary and glosses" (Reading Myth 6). The most important of these layers were the accessus ad auctores, prologues, which commented on the author's intention and the usefulness of the text for the reader. In other words, ancient texts were appropriated to fit doctrine by imposing an allegorical meaning in Christian terms upon them. Burrow describes medieval community as particularly "favourable to allegory, as all things and events were interpreted in light of potential communication with God" (96). Seen in the tradition of translatio, it is not surprising that an early fourteenth-century Franciscan friar 
reinterpreted Ovid's original Metamorphoses by "re-packaging" the fables within a Christian framework and adapting the original title to Ovide moralisé. This allegorical adaptation of the original Latin text will be helpful for the discussion of Yde et Olive, as its insistence on "cracking the shell" to find the deeper meaning, as well as its didactic components will help to place the discussion of Yde et Olive in the following chapters within that same tradition of "text renewal."

\section{Ovide moralisé: Christian doctrine in a Latin classic}

Ovid's Metamorphoses in its original form became popular in the twelfth century with the general tendency to translate literature from Antiquity into the vernacular. At the time of the creation of the Ovide moralisé, the "matter of Rome" had already gone through a long tradition of interpretation (Blumenfeld-Kosinski, Reading Myth 5). The new "version" of Ovid's text, however, differed greatly in that it added, in the tradition of glossing, thousands of lines of commentary that sought to adapt what was considered a rather controversial text. One should remember that Ovid himself had been banned from Rome after the completion of his work in 8 A.D. because of its anarchistic tone. In the introduction to his translation of the Metamorphoses, Howard Gregory states: "Practical statesman as Augustus was, he could not see or did not wish to see that his efforts to enforce the sexual moralities of ancient Rome by law was nonsense" (Intro xvii). Ovid's collection full of incestuous lovers certainly did not lose any of its scandalous flair with medieval clerics. If anything, it was probably looked upon with more disdain than ever. 
Hence, it is not surprising that the Ovidian text needed some "polishing" to be safe with the pious reader. The present discussion will be limited to the story of Iphis and Ianthe from Book IX of the Ovide moralisé, as it clearly served as the base for Yde et Olive.

Ovid's fable Iphis and Ianthe narrates the fate of a girl named Iphis, who is forced to live as a boy. Her mother Telethusa hides the female sex of her child because her husband Ligdus ordered to have the baby killed should it be a girl. Growing up as a boy, Iphis eventually falls in love with the beautiful girl Ianthe, which causes Iphis much grief and doubt in face of her "unnatural" feelings. In the meantime, ignoring the true sex of his son, Ligdus plans the happy wedding. When the situation threatens to get out of control, Telethusa goes to pray to the goddess Isis who grants Iphis the male sex so that the wedding with Ianthe can take place. The parallels in the plot to Yde et Olive are obvious, but that is not the primary focus here. Rather, the treatment of Iphis and Ianthe in the Ovide moralisé is typical in that it seeks to "metamorphose" Ovid's story into a Christian parable. ${ }^{8}$ Following the tradition of the medieval prologue, the author starts out by assuring that the ancient fables contain useful truths:

Et combien que l'on les nomme fables et que aucuns les dient mensongiers. Toutesvoies icelles bien entendues selon ce qu'elles seront cy après exposées

\footnotetext{
${ }^{8}$ I was unable to track down the original manuscript edition of the Ovide moralisé in verse form. Rather, I will take the following passage out of a prose version from the fifteenth century. Based on comments found in secondary sources on the original Ovide moralisé, it seems that the point being made here is supported with either version.
} 
on y trouvera de grans verités et moralitez prouffitables assavoir, ja soit ce qu'elles soient enveloppées et couvertes subtillement soubz fictions ... (44) The telling of the actual story follows closely the original Ovid. However, following the story, the reader finds an "exposicion allegorique" that interprets the fable in Christian terms. In it, the father Ligdus represents God, the mother Telethusa the holy Church and Iphis the sinful soul:

Par Ligdus devant nommé peut on entendre Dieu le Père tout puissant, qui contre humaine creature et pecheresse donna jadis sentence très redoutable, se elle ne se repent de ses pechez. Mais quand nostre Mère Saincte Eglise catholique a receü en son giron la creature, elle prie Dieu pour elle par chacun jour devotement ce qu'il luy plaise donner cognoissance et voulenté de delaisser ses pechiez, de soy amender, repentir, confesser veritablement . . (253)

Although for the modern reader, this technique might look rather crude, the Ovide moralisé is a perfect example of how biblical exegesis was sometimes forcefully transferred to the study of pagan texts; how the "Gold was taken out of Egypt." Of course, this is an extreme example of doctrinal "rewriting," which makes it quite humorous. As Blumenfeld-Kosinski comments: even if the Ovidian base was false from a doctrinal point of view, "it became true through the poet's ingenuity: the fables' hidden meaning was as orthodox as could be desired" (City of Scholars 5). This allegorical explanation of the Ovidian myth will become particularly important for chapter three discussing the parallels between Yde et Olive 
and Christian hagiography with Yde's function as an allegorical figure and the didactically moral message of the poem.

Among other critics, Burrow has underlined the importance of the Fourth Lateran Council of 1215 under Innocent III and its impact on thirteenth-century literature, as one of the doctrinal changes was a new law regarding confessions. Canon 21 of the council established the well-known "Omnis utriusque sexus," which demanded from all Christians to confess their sins at least once a year. Burrow comments: "Confessional moral psychology had, in fact, profound consequences for the literature of the later Middle Ages ... it made writers much more conscious of, and articulate about, the moral issues raised by their stories" (110). Seen against the background of the Fourth Lateran Council, the Ovide moralisé becomes all the more significant for the present study.

One might ask why Classical mythology seemed to lend itself so well to this kind of adaptation. Mythology typically talks of origins and cultural foundations, and with that, of the threat to those origins. Blumenfeld-Kosinski states that myths often become a space for the forbidden dangers to society, especially so in Ovid. With that, "the medievalization of classical subject matter allowed poets to encode their own political and poetic concerns via a displacement to the past" (Reading Myth 216). Speaking about the forbidden could also make an excellent moral case depending on the format used for the discourse. The next chapter will try to outline how the motifs of incest and cross-dressing in Yde et Olive present precisely some of those lurking dangers to the social and religious fabric of the time, before focusing 
on the more allegorical character of the poem in connection with the hagiographic tradition in chapter three. The depiction of these dangers certainly helped to make the moral message of the poem all the more powerful. That is, by first emphasizing the dangers in Yde's life and social environment, her development will be all the more meaningful. 


\title{
CHAPTER TWO: THE HIDDEN DANGERS TO MEDIEVAL LINEAGE
}

\begin{abstract}
Of such of these men as profess the grammar of love, some embrace only the masculine gender, some the feminine, others common or indiscriminate. Indeed, some, as if of heteroclite gender, are declined irregularly, through the winter with the feminine, through the summer in the masculine.
\end{abstract}

(Alain de Lille 463) ${ }^{9}$

Alain de Lille's De Planctu Naturae from the twelfth century reads as a sort of medieval law book that defines what constitutes "Nature." As Bloch has observed, the "straightness" or "regularity" of all things stands in the center of de Lille's debate. In drawing out what is the "lawful path of sure descent with Nature," the poet makes a connection between "straight" writing and "straight" sexuality (Etymologies and Genealogies 133). This discussion will be less concerned with the art of writing, but instead focus on the notion of regularity and straightness of sexuality and genealogy, as it applies to the central plot in Yde et Olive. As we have already seen in Chrétien's prologue to Cligès, the idea of straightness in genealogy

${ }^{9}$ Quoted in Bloch, Etymologies and Genalogies 135. 
permeated medieval thought. Bloch explains this phenomenon by describing the changes that took place in the twelfth century in regard to inheritance laws and how they affected the relationships between the people of a clan who were no longer dependent on the generosity of their patron:

... the family, narrowed around its outer edges, temporalized and rendered vertical, also underwent a reorientation, an axial shift, such that its articulation of itself acquired the dimension of a straight line. Linearity is the defining principle of the noble house, dynasty, and - the partial homonymy is striking - of lineage. (Etymologies and Genealogies 69$)^{10}$

Literature from around and after that time focuses on the question of genealogy and lineage and often points to the hidden dangers to that "straightness of descent." Examples of texts that discuss in some form or another the issue of genealogy, kinship or marriage spread throughout the period. Again, Marie de France's Lais figure as an example of a critical view on lineage and marriage practices. Maybe most significant for this study would be her lais Les Deus Amanz, in which the father's "unnatural" fixation on his daughter disrupts the family line, much like in Yde et Olive:

... mais le roi ne voulait la donner à personne, ne pouvant se passer d'elle. Elle était son seul réconfort, il ne la quittait ni nuit ni jour. La jeune fille était sa consolation depuis qu'il avait perdu sa reine. Beaucoup le critiquèrent à ce sujet, ses proches même lẹ blamèrent. (181)

\footnotetext{
${ }^{10}$ For additional studies on medieval kinship and families, see Duby, Love and Marriage in the Middle Ages.
} 
A motif that is often used in literature of the period, the king's refusal to give away his daughter brings about misery to the family. In Les Deus Amanz, the daughter dies at the end. Equally, in Yde et Olive, Florent's refusal to marry off his daughter will bring about the symbolic death of Yde: she casts off her feminine body and takes on the male shape instead. Medieval literature from that period is typically concerned with these kinds of familial disruptions. Perhaps most importantly for this discussion, the thirteenth-century Roman de Silence (Silence) by Heldris de Cornüalle comments on the question of lineage by using the motif of cross-dressing. It will therefore be helpful to include Heldris' text in the discussion, as it plays with confused gender norms, much like Yde et Olive. ${ }^{11}$

\section{The disruption of lineage}

Le Roman de Silence figures as a recent discovery by medievalists as it was published for the very first time in the 1960 s. The story line resembles that of $Y$ de et Olive in multiple ways. In both texts, the heroine is forced to cross-dress due to exterior circumstances; that is, she does not choose to do so by her own will. Secondly, both heroines succeed in their knightly duties so exceptionally that they are engaged into feudal services with a king. Eventually, they both become entangled in a potential relationship with a woman, which leads to the climax of the crisis. Finally, in both stories, the problem is resolved by reestablishing normal

\footnotetext{
${ }^{11}$ This brief mention of Silence does not do justice to the multiple layers of the text. Many articles have been published on it, particularly in the field of feminist criticism. Please refer to my bibliography for further reference.
} 
gender relations at the end, even if in two different ways. Silence and Yde et Olive both begin by setting up a situation in which the father refuses to accept the "normal" conditions of having a daughter; namely to allow her to seek exogamy, to break out of the family. Both fathers are fixated unnaturally on their daughters, even if there is a slight shift of focus between the two. In Heldris' text, the anxiety over lineage preservation is stated in an explicit way. Silence's father Cador wants to hide the sex of his child to secure her inheritance because the king passed a law that no woman shall inherit any land:

Consel nos concenra aquierre / Que nos oirs ne perge sa tierre. / Je le voel, biele, desguiser, / Si com m'oïstes deviser. / Faire en voel malle de femiele. (We ought to devise a plan / to keep our heir from loosing her lands. / Dearest, I want to disguise her, / as you heard me say before. / I want to make a male of a female.) (v. 2037 -2041)

Silence takes on her new role because of her father's obsessive behavior. In Yde et Olive, it is also the father who triggers the cross-dressing, and his thoughts are somewhat similar to Cador's. His refusal to give away his daughter in marriage could be interpreted as wanting to hold on to his kingdom:

Maint haut homme ont ma fille demandee; / Jou ne sai homme u mix fust mariee: / Dedens .j. mois l'averai espouzee.

(Many noble men have asked for my daughter; / I do not know any man to whom [my daughter] could be better wed: / Within one month, I will have married her.) (v. 6395 - 6397) 
But in Yde et Olive, the disruption caused by the father's obsession is developed further: not only does he refuse to give away his daughter, but he wants to actually marry her, thus posing as a direct sexual threat to her. The poet treats this introduction of the incest threat very carefully by leaving no doubt as to the gravity of the potential sin committed here. When the king announces his wedding plans, his counselor Sorbarrés immediately reacts with an outburst of horror. It may be important to know that Sorbarrés used to be a pagan chatelain from Bulgaria, who in a previous Huon episode realizes the power of God and eventually joins Yde's parents in Aragon. ${ }^{12}$ "Freshly" baptized, Sorbarrés seems to represent Christian morals when he exclaims: "A ceste loi que Dix nous a donnee, / Dedens infer sera t'ame dampnee" (With the law that God has given us, / Your soul will be damned to hell) (v. $6401-6402)$. Additionally, a few lines down, the poet laments on the poor choices made by the king that will disrupt the kingdom. This passage seems to lament the present state of affairs in general, thus underlining the preoccupation with lineage disruption:

Diu, pour coi a li rois tele pensee / Dont tante dame iert encor esplouree / Et tante terre et destruite et gastee, / Tante jovente en iert deshyretee, / Tante pucelle orphenine clamee?

(God, why does the king have such thoughts? / Because of which so many women will yet be wet with tears, / And so much land will be destroyed and

${ }^{12}$ This happens in the sequel Clarisse et Florent, which precedes Yde et Olive. 
devastated, / So many young people will lose their inheritance from it, / So many a maiden proclaimed an orphan?) (v. $6417-6421)$

As Durling points out, the public announcement of King Florent's intentions underlines that incest is a threat against the divine and legal context of the time: "The private, personal threat to Yde is therefore situated as part of a larger public threat, encompassing politics, governance, fertility, and legitimacy" (259). This threat is even more emphasized by the obvious lack of wisdom and stubbornness of King Florent who acts against all laws of morality and reacts to criticism with extreme defiance: "S’il est nus hom qui le m'ait desloëe, / Lués li aria l'ame du cors sevree " (If there is any man who blames me for it / I will immediately have his soul severed from his body) (v. 6404-6405). The integrity of the lineage is clearly at great risk. Following a similarly disruptive and obsessive pattern, Olive's father provokes a war with the King of Spain because he refuses his daughter to him. When announcing Rome's occupation, the king's messenger declares clearly that it would have been better to give away the princess in marriage:

Li rois d'Espaigne en a sa loi juree: / Anchois qu'il soit la quinzainne $\mathrm{pa}[\mathrm{s}] \mathrm{see}$, / Avra par forc[e] ceste grant tor quarree / . . / Pour vostre fille, qui li fu refusee. / Il venist mix qu'il l'eüst espousee / Que tant de gent en fust morte et finee.

(The King of Spain swore to them his oath: / Before two weeks will have passed, / He will have quartered by force this big tower / . . . For your 
daughter who was refused to him. / It would have been better if he had married her.) $(\mathrm{v} .6932-38)^{13}$

Throughout the poem, the theme of lineage reoccurs, not only with the actual plot but also with the use of language. Many critics have discussed the formula "son of..." or "daughter of ..." predominant in epic poetry as an insistence on kinship relations. ${ }^{14}$ Yde identifies herself on numerous occasions as the king's daughter, especially in situations where she needs to be exceptionally courageous and virtuous, such as when she is forced to fight a thief who urges her to join his band: "Bien doi avoir prouece et hardement / Quant je sui fille au rice roi Florent" (I must have a lot of prowess and courage / For I am the daughter of powerful King Florent) (v. 6800 6801). Being so courteous and wise, Yde knows that she needs to make up for the lack of wisdom of her father who has proven to be unfit to secure the kingdom. His obsessive behavior disrupted the family line and made him fail in his duties as a father. In a rather symbolic way, Yde even states that her father is "dead," thus pointing to his inability to reign: "Or est cis mors qui ici m'amena" (The one who brought me here is now dead) (v. 6616). Yde's cross-dressing brings about a definite shift in power within her family, as she no longer seems to respect her father as the controlling force in her life. Instead, she steps into the leader role that her father did not manage to uphold. Whereas her father was the head of the family, she now seems to outrank him. It is interesting that King Florent disappears completely from

${ }^{13}$ At the same time, this scene also recalls the traditional role of the woman as peace weaver in Anglo-Saxon literature; that is, a war could have been avoided with Olive's marriage.

${ }^{14}$ See for example: Chickering, Howell D, Beowulf 300. 
the plot from the moment of Yde's escape. In a later episode of the Huon de Bordeaux cycle, the poet will inform the reader of King Florent's death without bringing him back again. Again, the poet seems to make a statement as to the great immorality of Florent's incestuous desire. That is, the king's unworthy behavior does not grant him another appearance for the rest of the cycle. It will be helpful to examine the motif of incest in medieval literature a little further as it plays such a crucial role in Yde's story.

\section{The ambiguous treatment of incest in medieval literature ${ }^{15}$}

Durling explains the use of the incest motif in the poem with the fact that the story preceding Ovid's Iphis and Ianthe in The Metamorphoses deals with incest as well: Byblis falls desperately in love with her own brother and suffers metamorphosis at the end. Durling states: "It is tempting to think that the popularity of this incest story might have suggested to the Yde poet his conflation of mythic topoi: incest and gender change" (257). Certainly, the migration and clustering of classical motifs played an important role in medieval literature. The connection to Biblis even goes further, it seems. Just as Biblis is transformed into a fountain due to her incestuous desires, Yde is ultimately transformed into a man due to the incest threat posed by her father, which makes Durling's point valuable. However, the use of the incest theme in literature can certainly be traced back to contemporary social concerns as well.

${ }^{15}$ The following arguments will be largely based on Gravdal's research on incest in the Middle Ages. 
Again, the Lateran Council of 1215 serves as pertinent background to this discussion for it is under its new rule that incest is redefined to include up to four familial degrees, instead of the previous seven degrees, as established in the eleventh century (Gravdal, Comparative Literature 281). The Yde et Olive poet is well aware of this new regulation, as Florent's counselors clearly define the law before the king:

Le marriage, quant il le commanda, / Tous crestïens Jhesucris commanda / C'a son parage ne se mariast pas: / Tu ne le pues avoir dusques en quart, / U autrement bougrenie sera.

(When he ordained marriage / Jesus ordered every Christian / Not to marry his own kin: / You cannot have [do] it before the fourth degree, / Or otherwise it will be heresy.) (v. $6485-6489)$

Many sources attest to the fact that medieval people were well aware of the hidden danger of incest. In terms of literature, authors certainly were inspired by the Classic myth of Oedipus, even more so because its tragic hero commits the mortal sin without knowing it. In fact, Boswell names as one of the chief arguments against abandoning children in the Middle Ages this fear of unconscious incest, this fear that one might eventually engage in sexual relations with his own child without knowing it (392). Further evidence for the preoccupation with incest lies in the inclusion of the motif in some of the most central stories of its literary culture: Charlemagne and Arthur, two of the most central literary figures are both accused of incestuous relations (Gravdal, Forum 2). Thomas Aquinas described incest as repulsive and unnatural, but then turned around and said "that living at close quarters is bound to 
inflame lust, and so family life would make incest all too easy, if it were not forbidden" (in Gravdal, Forum 4). Moreover, Gravdal's study shows that there seems to be a new vogue of incest stories in literature in the twelfth and thirteenth century, a phenomenon that she explains as follows:

There are other aspects of medieval society ... which could help account for it, however: one is the development of the theological doctrine of contritionism, and the other is the church's campaign to enforce the consanguinity laws. (Forum 5)

As mentioned, the Fourth Lateran Council also established a new law for yearly confessions, and it is in the backdrop of those two new regulations that the treatment of the incest motif needs to be examined. Walecka discusses the etymology of the word "incest" as coming from "in-chaste," or sexually active. Consequently, the term "incestuous" in medieval vocabulary could broadly mean "sexually active" (117). With the new focus on penance, incest came to be understood as a general expression for "original sin," and was used as a motif in literature to exemplify the pious' need to confess. However, in Yde et Olive, the father does not seem to repent at all; on the contrary, he completely disappears from the scene after his daughter's escape. So where does the moral lesson about incest lie in the story? A partial answer can be found in medieval Church penitentials, handbooks for priests to assign penance according to the gravity of the sin. Gravdal gives the example of the Canons of Theodore that lists all different kinds of penances for sexual intercourse within the nuclear family, and "it is most striking that there is no mention of the 
possibility of incest committed by the father" (Comp Lit 282). Moreover, legal documents from the period show that a woman who killed her baby born of an incestuous union was penalized harshly, but the original perpetrator was not. Of course, this "gap" in legislation could be explained in many ways, but there certainly seems to have been a double standard in the treatment of incest cases when it came to the father as perpetrator. Gravdal examines how the genre of incest stories developed in the twelfth century, and a comparison of these general tendencies to the treatment of the motif in Yde et Olive will demonstrate some valuable points for this discussion.

Particularly useful for the present focus, Gravdal examines the development of the incest motif in the romance genre, which again clearly points to a double standard: in incest stories of mother and son relationships, the incestuous son goes on and becomes some sort of saintly hero, whereas the mother's story line focuses on penance (Comp Lit 285). In stories of father-daughter relationships, however, the father typically disappears from the scene, and the daughter seems to be thrown into a series of adventures. In de Beaumanoir's La Manekine, a text that critics have used in comparison to Yde et Olive (see introduction), the heroine has to suffer through a series of events that violate her over and over again, without her being able to defend herself:

[A]lthough the lesson comes through the crime of the father ... the long penance is in fact acted out by the innocent daughter, Joïe, who must on two 
occasions go out into the world unprotected and suffer hardship and indignity before being restored to take her station and birthright" (Comp Lit 286). The daughter is forced to live out the penance for the sins committed by her father! Importantly, the final outcome is always a positive one, as if in a perverted sense, the sexual abuse to the daughter contributed to her moral growth. Gravdal remarks that despite the lack of glory in the daughter's journey, it nevertheless allows for a literary innovation, namely placing a woman as protagonist of the story (Comp Lit 286). Taking now these two different treatments of the incest motif and applying them to Yde et Olive, the poet seems to have combined typical elements of both the mother-son, as well as the father-daughter version. As mentioned, the father disappears from the scene, but Yde clearly accuses him of his indiscretion against her. The father's disappearance does not contribute to the covering up of his sins; on the contrary, it seems that the father's failure seems to be unforgivable; he does not get a second chance in the plot to make up for it. Yde says it clearly: "Or est cis mors qui ici m'amena" (The one who brought me here is now dead) (v. 6616). However, Yde still seems to be punished for her father's sins, as she is forced to escape and engage in a series of adventures. But unlike the typical passiveness of the incest heroines during their picaresque adventures, Yde takes on what resembles much more the son's role in the mother-son motif. Her strength and courage propel her into a series of adventures that will only help to establish her glory. She resembles much more a saintly hero than a miserable daughter on a journey of penance. 
Overall, Gravdal makes another important observation: classical incest stories end tragically, whereas medieval incest stories seem to end happily (Forum 2). Going back to Ovid, Biblis' metamorphosis is depicted as an extremely tragic end: "So all of Byblis melted into tears, / And is that fountain in a distant valley, / A stream that has her name, that rises, falls, / And flows beneath a dark-leaved ilex tree" (The Metamorphoses 265). Of course, since Yde et Olive mixes the two motifs of incest and cross-dressing, the parallels cannot be drawn cleanly, but the poem certainly ends on a happy note with a marriage. And incest, as in the typical fatherdaughter treatment of the motif, ultimately leads to an ending that is for the greater good of everyone. The sexual threat posed by her father pushes Yde to cross-dress, which ultimately results not only in her moral development, but also saves the kingdom of Aragon.

\section{Cross-dressing as disruption or protection of the family line?}

Cross-dressing in the world of Alain de Lille is certainly considered as a deviation in the straight order of nature figuring as a force just as disruptive as incest. However, cross-dressing in medieval literature seems to contain other dimensions beside that of acting as a disruptive force. In fact, going back to Silence, the father plans to cross-dress his daughter to protect his family, which seems almost to invert the basic notion of cross-dressing. That is, normally, the act of cross-dressing threatens societal order, as it refuses to follow the norm of established gender relations, however, in this case, cross-dressing is used in an effort to achieve and 
preserve order within the family. Equally, Yde's cross-dressing does not disrupt society, but actually helps to establish order. ${ }^{16}$ Forced to escape her father's advances, cross-dressing is a means to preserve not only her own dignity, but also her family's honor. Walter underlines that whereas cross-dressing is a sin against nature, Yde only commits that sin to avoid an even greater one (315). The poet underlines that her morals remain intact at all times. When she arrives in Rome and King Oton asks her about her skills, she puts her religious and moral convictions first: "Premiers sai bien Jhesucrist aourer / Et a prodomme mout grant honor porter" (Above all, I know well how to pray to Christ / And to bring great honor to an honest man) (v. 6884-6885). The poet also insists on numerous occasions that $\mathrm{Yde}$ is forced to cross-dress to keep her honor; that is, that her father forced her to do so. When faced with the impending marriage, Yde laments her fate:

Glorious Dix, qui mains en Trinité, / De ceste lasse cor vous prengne pités, / Cui il convient par force marïer. / Hé ! Florent, peres, com eüs mal penser / C'a nul baron ne me vausis donner, / Ains me cuidas a moullier espouser: / Mix me laissasse en .j. fu embraser! / Jou m'en fuï pour la honte eskiver / De ton païs par ton pecié mortel.

(Glorious Lord, who resides in the trinity, / Take pity on this wretched body, / That is forced to marry by necessity. / Hey! Florent, father, what terrible thoughts you had / That you did not want to give me to any baron, / Rather

\footnotetext{
${ }^{16}$ The following chapters will examine cross-dressing with a different focus. For now, I am primarily interested in issues concerning the preservation of the family line.
} 
you thought of taking me as your wife: / Better to have let me burn in a fire! / To escape the shame, I fled / From your land because of your mortal sin.) (v. $7106-7114)$

There are numerous other passages in which Yde laments her father's lack of morals and even prays for his salvation: "Sovent prioit pour roi Floire, son pere, / Pour cui ele est si tainte et mascuree" (She often prayed for King Florent, her father, / Because of whom she was so dirty and stained) (v. 6917-6918). These lamentations are usually placed in moments of tension in the poem to underline again King Florent's role in bringing this crisis upon Yde's life. When she engages in battle to save the Roman kingdom, she prays again: "Vrais Dix, sekeur ceste lasse caitive, / Qui pour honor est com uns hom cangie!" (True God, save this tired captive, / Who for honor changed into a man!) (v. 6995 - 6996). This emphasis on exterior circumstances forcing Yde to act the way she does, contributes to establishing her as a noble hero(ine) beyond any doubt, again mirroring the plot of Silence, where the heroine establishes her noble character as a knight. But naturally, something has to happen in the end to resolve the social dilemma that cross-dressing always brings about. As mentioned, both Silence and Yde et Olive reestablish balance, but they do so in different terms. Silence concludes in an elegant solution that reestablishes the heroine as woman and wife of the king whom she served as knight before. Moreover, inspired by Silence's moral worth, the king decides to change the inheritance law back to include daughters. The poet concludes on a 
moral tone by praising Silence's virtue as a woman, emphasizing her superior worth considering that women are naturally less inclined to act morally than men:

Car feme a menor oquoison, / por que ele ait le liu ne l'aise, / De l'estre bone que malvaise, / S'ele oeuvre bien contre nature.

(For a woman has less motivation, / provided that she even has the choice, / to be good than to be bad, / Doing the right thing comes unnaturally to her.) (v. 6688-6691)

In Le Roman de Silence, the heroine is put back into her "natural" place of the conventional societal order and the poet who allowed his heroine to be so virtuous, falls back into the standard misogynist discourse of the period. In contrast, the poet of $Y$ de et Olive chooses to metamorphose his heroine into a man to establish balance in the end. In either poem, everybody assumes their "natural" place, and to assert even further that order has come back to the family line, Yde et Olive concludes with the divine announcement that there will be progeny. The angel pronounces:

Otes, bons rois, dedens .vjjj. jours venrés / En l'autre siecle, de cestui partirés, / Et vostre fille avoec Ydain lairés: / .I. fil aront, Croissans iert apellés;

(Oton, good king, you will come within eight days / Into another life, you will leave this one, / And will leave your daughter with Yde: / They will have a son, he will be called Croissant.) (v.7274 - 7277)

The family line is secured and the son's name "Croissant" certainly also points to the "growing," the continuation of the family line. This going back to the "status quo" 
of gender relations is typical for medieval literature that plays with gender and crossdressing, as Perret suggests (329). In that respect, it is interesting to compare the ending of the original poem Yde et Olive to that of the late fourteenth-century Marian play Miracle de la fille d'un roy, which is its dramatic adaptation (see introduction). In the Marian miracle, Ysabel's (for Yde) transformation is only temporary: the play concludes with Ysabel's marriage to King Oton of Rome and Olive's marriage to King Florent of Aragon. ${ }^{17}$ Clark comments:

The return of the father is doubly crucial in that it allows the redistribution of the improperly married woman into culturally sanctioned sexual arrangements; and it also allows Ysabel's "spouse" to replace Ysabel as a substitute for the dead mother, thus closing the breach opened at the beginning of the play by the threat of incest. (97) It is as if the original ending was not quite "smooth" enough for a late fourteenthcentury Christian audience by not allowing King Florent to "make up" for his sins and by actually changing Yde into a "real" man.

The motives of incest, abnormal sexual relations and cross-dressing serve to establish a situation of danger and disruptive forces in the plot that sets the "stage" for what will be the resolution of all this tension, leading to the climax of the moral message. This message is transmitted through Yde's gradual transformation. The next chapter will explore the significance of that metamorphosis in the context of hagiography and medieval philosophy.

${ }^{17}$ Unfortunately, I could not find an actual copy of the play. Clark mentions this alternate ending (97). 


\section{CHAPTER THREE: YDE ET OLIVE IN THE TRADITION OF}

\section{HAGIOGRAPHY}

Let Mary leave us, for women

are not worthy of life. [But] Jesus said, I myself shall lead her, in order to make her male, so that she too may become a living spirit, resembling you males. For every woman who will make herself male will enter the Kingdom of Heaven.

Gospel of Thomas $51.19-26^{18}$

The previous chapter mentioned the significance of cross-dressing as a disruption of society and the poet's reversal of that notion by using cross-dressing as a means to secure the family line in Yde's case. However, the story of Yde's gradual transformation into a man can be viewed in a strictly religious context as well. Naturally, fourteenth-century society found its base in Christian doctrine, so the social and religious contexts will blend into each other. Chapter one showed the relationship between Yde et Olive and the Ovide moralisé, which equaled Iphis' figure with the sinful soul that finds salvation in repenting its sins. The present

\footnotetext{
${ }^{18}$ In Robinson, James M., ed. The Nag Hammadi Library.
} 
chapter will develop this idea by relating Yde's transformation with contemporary philosophical views and ultimately with the genre of hagiography.

\section{The concept of male and female}

As the medieval world explained everything in relation to God's presence in the world, religious thought proceeded in a very linear fashion; that is, people looked at the physical world as a mirror to the spiritual. Exterior signs were transposed to represent interior values; that is, physical appearance represented directly the status of spiritual growth. This one-to-one conversion is a recurring aspect in the literature of the period. As an important influence, even the Rule of St. Augustine shows a nice example of this thought model in its description of how to attain the highest level of humility. It clearly states the importance of exterior signs, as the highest step of humility is reached "when a monk shows humility in his heart and in his appearance ... head down, eyes on the ground " (61). However, the most obvious examples of this linear connection between exterior and interior values can be found in the medieval fashion of portraiture. In Einhard's Life of Charlemagne, the emperor's physique is described in flattering terms. Einhard even devotes an entire section of his biography to "His Physical Nature." His body is "large and strong, and of a lofty stature, though not disproportionally so since his height is known to have been seven times the length of his foot" (Carolingian Civilization 35). Not only is he handsome, but the proportions of his body coincide with the holy number seven! 
Charlemagne's biographer uses such physical descriptions as a tool to underline the spiritual qualities of the leader.

In a world where physicality had such significant inner meaning, misogyny was greatly based on that same concept, basing its assertions on Aristotle's view of women as "defective men." Bullough describes Aristotle's "scientific" proof for male superiority: "Proof of such a conclusion ... could be observed in nature, where the male of each species was demonstrably more advanced than the female - larger, stronger, and more agile" (Bullough, Cross Dressing 46). Again, physical strength is equated with spiritual greatness. This reliance on exterior signs helped to support the notion that man was superior to woman, proven by his exterior shape representing his inner worth.

More importantly for this study, Aristotle's hierarchic view of the world, where things have the potential to change and evolve from their present status to a "higher" form, shaped the medieval mind (Knowles 13). The next step in this thought model was an easy one: Women who wanted to improve their worth were encouraged to model men. "That a female might desire to be a male, in fact, seemed to be a healthy desire, a "normal" longing not unlike the desire of a peasant to become noble" (Bullough, Cross Dressing 67). This, of course, needs to be understood more as a theoretical model than a representation of the social climate. It merely means that fourteenth-century society was rather tolerant toward female cross-dressing, accepting it as a norm. Women who overcame their female body were praised as increasing their spiritual worth, as becoming male. Seen in the 
context of St. Jerome's famous quote, medieval cross-dressing takes on a new meaning: "As long as a woman is for birth and children, she is different from man as body is from soul. But when she wishes to serve Christ more than the world, then she will cease to be a woman and will be called man" (qtd. in Davidson 66). Numerous clerics asserted this belief, seen for example in the writings of Isidor of Seville, Bernard of Clairvaux, or William of St. Thierry who explains the process of spiritual growth as follows:

When [the soul] begins to be not only capable but also in possession of perfect reason, it immediately renounces the feminine gender ... For as long as it is anima it is quick to slip effeminately into the carnal; but the animus or spirit thinks only on what is virile and spiritual. (qtd in Wild 52, my emphasis)

Moreover, this belief of a female-to-male transformation on a religious and philosophical level was also based on certain medical views of the time. Particularly influential in medieval medicine, the second-century physician Galen describes the female sexual organs as male organs turned inside out. Galen explains this phenomenon with the woman's deficiency of bodily heat: "For the parts were formed within her when she was still a fetus, but could not because of the defect in the heat emerge and project on the outside" (qtd. in Bullough, Viator 492). Bullough states that popular literature from the period took that idea and developed it, circulating the common notion that women who spread their legs too far would have their organs fall out and become men (492). Although an anecdotal truth, the logic 
thought behind it can be easily applied to medieval social practices, where women were kept inside in the private sphere, while men emerged into the public sphere. Women remained inactive because they were cold by nature. They were to be kept inside, just as their organs were kept inside (Bullough 27). However, when a woman did step into action, she "increased her heat," moving toward the male element by becoming more present and visible, visible like the male genitals. "Heat might 'ripen' [women] and cause their dormant maleness to emerge, the woman giving rebirth to herself as a man" (Davidson 65).

In Yde et Olive, both the spiritual and the more social component of "becoming male" are present. Her cross-dressing not only gives her a higher status in society, but she also undergoes a spiritual growth that is based on assuming her male role. Clearly, she has become more worthy in the eyes of God and is therefore granted her new sex by an angel directly sent from Heaven. And it is exactly this basic belief of "becoming male" in a spiritual sense that hagiography adapted into the genre, creating a whole corpus of literature about "transvestite saints." Hagiography plays a central role in this discussion as many elements used in this genre appear also in Yde et Olive.

The tradition of hagiography and the phenomenon of transvestite saints

The basic genre of hagiography or the Vitae of saints dates back to the early Church fathers. The phenomenon may again be best explained by the linearity of medieval thought, by the attempt of early Christians to visualize God's power in 
order to prove to non-believers the proximity of this new God in the world. That is, God's persona manifested itself to the believer through miracles, visual proof of his omnipresence and power. As pagan religions were much based on concrete rituals and images, Christian writers relied on giving visible proof for God's existence as well. For early Christians, seeing was believing. In the fifth century, this proof was found in the lives of saints that were filled with miraculous events. In the Life of Martin of Tours, Sulpicius Severus includes numerous examples of such miracles. God acts through St. Martin when he fights a fire that threatens to destroy a sacred shrine: "there appeared to be a sort of conflict between the elements fighting each other. And so, as a result of Martin's special power, the fire only had an effect in the place where it was ordered to do so" (Early Christian Lives 147). The majority of the Vitae of saints are embedded in the culture of early Greek monastic communities, evolving around the desert of Scetis. Anson comments: "Such a grouping suggests that the legends may have been mass-produced by a school of Egyptian scribes at a time when the desert of Scetis had become the acknowledged center of the monastic movement" (12).

The Vitae of female transvestite saints can be looked at as a sub-genre of hagiography and has to be understood in the context of women "becoming male," as discussed in the previous section. Anson talks of an entire literary cycle of transvestite saints' Vitae (13), when he outlines the development of the genre in three important phases, which will become significant for this study. Hagiographies of early transvestite saints seem to focus primarily on the spiritual transformation and 
new identity: The heroine renounces her femininity by donning male clothing, symbol of her religious commitment. She enters a convent in disguise where she lives in great humbleness and is not found out until after her death. The stories are accompanied with the usual miracles, following the hagiographic blueprint. With time, however, these Vitae are developed to incorporate a world of erotic romance. A popular motif is what is commonly referred to as the motif of "Potiphar's wife": A wealthy wife becomes attracted to the saint in man's disguise and accuses her of being the father of her child. The saint accepts the accusation without protest and endures the trial silently without revealing her true identity. The revelation of her true sex after death becomes all the more powerful, as the monastery realizes the wrongs that were committed against the holy martyr. The psychological focus lies here with the monastic community. Anson speculates: "Thus, quite simply, the secret longing for a woman in a monastery is brilliantly concealed by disguising the woman as a man and making her appear guilty of the very temptation to which the monks are most subject" (30). Finally, the legends begin to resemble more and more the romance genre, focusing on the psychological development of the heroine who accepts the wrong accusations to be purged from her own sins.

Moreover, in later versions of hagiography that involve female transvestite saints, cross-dressing often affects a positive change for the heroine's environment; that is, cross-dressing serves not only to protect the heroine's integrity, but also takes on significance beyond her own persona (Anson 16). In the Life of Euphrosine, the daughter escapes the marriage plans of her stubborn father and secretively joins a 
monastery. In search of consolation for his loss, her father chooses her as spiritual guide without knowing her real identity. In male disguise, the daughter is able to establish a meaningful relationship with her father and to reason with him. Hotchkiss points out that female cross-dressing in hagiography often fosters domestic harmony:

While many of the transvestite saints leave their homes and families with no further thought of their worldly past, others, such as Athanasia, Eugenia, Euphrosine, and Hilaria, use disguise to redefine familial relationships. These women earn recognition and praise from their male family members only after effacing gender. (28)

This shift in the father-daughter relationship also becomes interesting in terms of power. Whereas before, the father decided everything about his daughter's life, it is now the daughter who guides her father in return. In Yde et Olive, a similar shift of power has taken place, as discussed in the chapter on lineage. Both Euphrosine and Yde change the power relations of their families by cross-dressing as a man.

Although the poet does not give Yde the opportunity to find reconciliation with her father, her cross-dressing is nevertheless for the greater good, as she saves the family line and produces a legitimate heir, thus protecting the kingdom of Rome as well as Aragon. Her cross-dressing serves the greater community, which again, is a motif found in the Vitae of transvestite saints. The Life of Saint Eugenia uses the motif of Potiphar's wife (see above), describing a heroine who accepts quietly the unjust accusation of fathering a child. After her death as a martyr, her virtue and noble 
suffering impress the people so much that the revelation of her true identity brings about the conversion of her entire family. Moreover, the pagan potentate, known for his harsh treatment of Christians, is so moved by Eugenia's piety that he grants freedom to the entire Christian community (Anson 23). ${ }^{19}$

But this is only one small detail of many common aspects between Yde et Olive and these later versions of the legends, from which the poem seems to borrow its material. A more detailed description of hagiographic features found in the poem will illustrate the connection to that tradition.

\section{Parallels of basic structure between the Vitae and Yde et Olive}

The stories of the lives of transvestite saints are typically developed in a three-part structure: they usually begin by describing the heroine's flight from the world. Due to her exceptional virtue, she is compelled to seek a religious life, away from worldly corruption. The middle section narrates her disguise as man and seclusion from the world that enables her to pursue her calling and develop her spiritual worth. At the end, her true identity is revealed, often in a great scene of a public trial, or anagnorisis (recognition). The motif of flight was gradually developed in later texts, again by incorporating sexual elements: the heroine not only flees the pagan world in general due to its unworthiness, but faces an actual sexual threat, often in the form of incest, such as in the Vita of St. Hugolina:

\footnotetext{
${ }^{19}$ This motif of "the greater good" is also used in Silence: the King changes the inheritance law to include women based on Silence's virtuous behavior.
} 
To consider only those lives where disguise is central, ..., there are several [where] flight from the world explicitly represents flight from shame as well. Thus, Hugolina flees the threatened defilement of incest, and Agnes of Moçada that of enforced marriage. (Anson 13)

There is a whole set of women saints, the so-called "monachoparthenoi," or virgin monks, who flee sexual threats by donning male clothes (Hotchkiss 22). With the development of these motifs to take on higher stakes, the climax of revelation at the end becomes more and more dramatic.

A comparison to Yde et Olive shows obvious parallels of the basic pattern of flight, disguise and recognition. The incest motif is strongly present throughout the poem, as the poet makes sure that the reader is reminded repeatedly of why Yde disguises herself as a man. As shown in the discussion on lineage of chapter two, verses $6917-8,6995-6$ and $7106-14$ attest to the poet's insistence on underlining that threat, a threat that is primarily directed towards Yde's body. The predominant theme of Yde protecting her body through cross-dressing takes up the main part of the poem. Having shielded herself against her father's advances, she embarks on a series of adventures that develop the same theme of danger further, danger that always seems to be directed towards her body. Soon after she escapes the Spanish military attack, she meets a band of thieves who threaten to kill her. At their meeting, Yde underlines her potential vulnerability when she explains to the thieves: "Par foit, mes grans peciés, / Il n'a o moi plus de gens, ce saciés" (By faith, to my great misfortune, / There is no one with me, be assured) (v. 6706-6707). By her 
virtue, she escapes the thieves and reaches her destination. Finally safe under the protection of King Oton, her body once again is threatened in a sexual context when his daughter Olive falls in love with her. Here, the poem stays ambiguous about Yde's feelings to Olive, never stating clearly how she feels about the princess. This constitutes a departure from Ovid's original that focuses on Iphis' feelings for Ianthe and her doubts about her own nature. Ovid's Iphis laments:

Cows have no love for cattle of their gender, / Nor mares for mares; the ram leaps on the ewe, / The frail doe runs her mazes toward the stag, / So birds in airy flight meet, male to female, / Nor any creature couple kind to kind / If only I were not a girl .... (Iphis and Ianthe 267)

She is desperate about her attraction, whereas Yde never seems to become actively interested in Olive. Durling observes: "Yde's own emotions, unlike Iphis's, remain curiously unengaged ... Yde is never presented as a desiring subject; rather, she is consistently portrayed as the object of a desire that is dangerous" (261). Yde never talks about her feelings towards Olive, but focuses on the dilemma that the marriage causes for the integrity of her body. That Olive's infatuation with her presents yet another threat to that integrity becomes obvious in the passage where Yde laments the threat of her father right before invoking Olive's feelings for her:

Jou m'en fuï pour la honte eskiver / . . / En maint peril a puis mes cors esté. / Or me cuidai dedens Romme garder, / Mais jou voi bien mes cors ert encusés. / La fille au roi a mon cors enamé; / Or ne sai jou comment puisse escaper. 
(To escape the shame I fled /.../ My body has been subject to many dangers since. / So I thought to keep safe in Rome, / But it is clear that my body will be revealed. / The king's daughter fell in love with my body; / Now I do not know how to escape.) (v. $7113-7119)$ This passage shows several important aspects for this discussion. First, it emphasizes the repeated threats to Yde's integrity, of which Olive's feelings are yet another example. Moreover, its insistence on Yde's body ("en maint peril a puis mes cors esté" and "la fille au roi a mon cors enamé") evokes the notion of virginity, of physical integrity that plays such an important role in the lives of saints. The integrity of Yde's body is threatened, and while she was able up to this point to protect her body, she does nof see a solution for her present dilemma ("or ne sai jou comment puisse escaper"). A few lines further down, Yde gives in and places her trust in God: “J'espouserai la fille au couronné, / Si face Dix de moi sa volonté” (I will marry the daughter of the crowned one, / And may God do with me as he wishes) (v. 7128 - 7129). Her trust in God will be rewarded with her taking on a new gender, which will solve the problem. Yde's cross-gender transformation allows her to stay faithful to the king and her beloved without committing an "unnatural" act, without compromising her body. She remains physically unharmed. A general insistence on Yde's physicality can be seen throughout the poem; that is, the language used to describe the heroine evolves often around her physical attributes, such as in line 6812 , in which the poet calls her "la bele o le cors gent" (the beautiful with the fair body) or in line 7248 , in which she is referred to as "Yde 
au cors mollé" (Yde with her shapely body). Likewise, in line 7107, Yde laments her "lasse cors" (wretched body), again pointing to the problematic of her body.

The theme of the virgin body certainly plays an over-all crucial role in Christian writings. Not only hagiography, but also poems based on biblical narratives use the motif repeatedly by showing virgins fighting against dangers to their bodies. The Anglo-Saxon poem Judith tells of Judith's victory over the pagan leader Holofernes who tries to violate her: “. . . the holy woman had / Been taken to his tent. The famous prince / Of cities then exulted in his heart, / Planned to pollute that lady fair with $\sin$ / and foulness ..." (in Hamer 139). In fact, Yde's fight against the band of thieves calls to mind the fight of Judith and Holofernes, both talking of the foul smell of evil. After killing the bandleader, Yde exclaims:

Fil a putain, mauvais larron pullent, / vo traïsons ne vous vorra noient. / Vers moi avés pensé vilainement. / Cis a luitiét; je croi qu'il s'en repent. (Sons of whores, stinking, bad thieves, / Your treachery will not be worth anything to you. / You had evil intentions towards me. / This one fought; I think that he regrets it.) (v. $6794-6797)$ Just as Yde, who fights off the thieves and eventually saves the Roman kingdom from the Spanish, Judith not only fights off Holofernes, but also saves the entire city from the pagans: "Then in the fight had Judith won herself / Outstanding glory, as God granted her" (145). Just as Yde's trust in God, Judith's faith helps her to prevail against evil. These fights against pagan adversaries seem to be a variation of the fight against the devil in early hagiography, a standard motif used in virtually all 
Vitae of saints to illustrate the solidity of their Christian virtue. Again, the fifthcentury Life of Saint Martin by Sulpicius Severus serves as a good example. In it, the devil takes on the shape of Christ, but:

$\ldots$ as a result of the spirit's revelation, Martin understood that it was the devil, not the Lord, and so he said, 'The Lord Jesus did not foretell that $\mathrm{He}$ would come in splendid clothes and with a shining crown; I will not believe that Christ has come unless He wears the same garments and has the same appearance as at the time of his suffering, and unless He bears the marks of the cross.' At these words the devil immediately vanished like smoke. He filled the cell with such a strong smell that he left clear proof that he was the devil. (157)

As in Yde et Olive and Judith, the evil is associated with bad smell. Moreover, Martin seems to fight off the evil not only by his strong belief, but also with the strategic use of his words, which resembles Yde's method as well. During her confrontation with the thieves, who want to kill her immediately, she reasons with them:

Dist la pucelle: 'Et pour coi vous coitiés? / En moi mourdrir arés poi gaaignié. / Je me rednrai a vous mout volentiers : / Tenés m'espee et si vous apaisiés / . . / Li maitres dist : 'Vien avant, escuiers. / Si m'aït Dix, tu n’i seras touchiés. / Ains vous donrai quanques mestiers vous iert.' (The maiden said: 'And why are you in such a hurry? / You will have little gained by my death. / I will gladly surrender to you: / Take my sword and be 
appeased / . . . / The leader said: 'Come forward, squire. / So help me God, you will not be touched here. / Rather I will give you whatever you need.') (v. $6713-6721)$

She eventually convinces them to fight according to her own terms and wins the battle. Obviously, Yde is aware of her reasoning skill: When King Oton asks her how she could serve him, she responds by listing her Christian virtues, immediately followed by her verbal skills:

Premiers sai bien Jhesucrist aourer / Et a prodomme mout grant honor porter, / Le povre gent de mon avoir donner / Et l'[orguil]lous par paroles mater. (Above all, I know well how to pray to Christ / And to bring honor to an honest man, / To give my possessions to the poor / And to defeat the haughty with my strategic words.) (v. $6883-6886)$

Her trust in Christ as well as her wisdom helps Yde to prevail against evil. In standard hagiography, the devil's appearances are connected with the idea of temptation. Again, the episode of the thieves in Yde et Olive serves well to show the parallels, as they offer her to join them in their band, but she refuses, clearly separating her lineage from the evil temptation of such work:

... ce n'est pas courtoisie. / De larrechin ne me mellerai mie. / Ains 1'ot larron en toute ma lignie (. . that is not courteous. / I will not get involved with robbery. / Never has there been a thief in my family line.) (v. 6749-6751) 
Thus, there seem to be two kinds of threats or temptations in hagiography: The standard threat of evil that the male saints have to confront, and the more sexual threat towards the integrity of the body against which the female saints have to fight. This development of the general motif of temptation into the motif of a direct sexual threat with female protagonists is a logical one when seen in the greater context of medieval thought. As Yde acts as a woman and a man in the poem, both types of threats are present: As a knight, she fights the pagan lords, as a woman she protects her body by fighting off the threat of incest and same-sex relation.

It becomes evident that the corporality of Yde seems to take an important place in the poem. In fact, medieval heroines never seem to escape their corporality, even in a saintly context. Cazelles discusses this phenomenon by relating it to erotic language found in the Song of Songs with its imagery of the bride of Christ. Female martyrs were often described as awaiting the "celestial bed;" that is, their union with God. And although official doctrine emphasized its strictly spiritual sense, the basic vocabulary to describe such a union still remained very much in the physical realm. ... virginity is, therefore, subject to ambiguous treatment in the portrayal of female perfection. In her lifetime, the heroine must remain chaste at all costs, chastity being the price that guarantees her salvation. But chastity is also to be offered and surrendered in the afterlife, with the result that corporeality remains the one and only means of assessing female virtue. (Cazelles 69) 
That is, the female saint always stays limited in her spirituality due to her body: She always stays fe-mina; that is, "of lesser faith" (Cazelles 48). ${ }^{20}$ Equally, in the legends of virgin monks, the heroine remains locked up in her physicality. Even cross-dressed as man, the transvestite saint who attempts to negate her sexuality always keeps her role as an object of temptation, such as in the motif of "Potiphar's wife" (Hotchkiss 24). In many legends of transvestite saints, the cross-dressed saint even has to be locked up in a solitary cell because the other monks are tempted by her persona without consciously knowing that she is a woman (Anson 16). A further example of this focus on corporality can be found in the Legend of Pope Joan that tells the story of a transvestite monk who moves up so high on the ecclesiastical ladder that she becomes elected Pope. However, she finally gives into her temptation and becomes pregnant by a monk. The legend has her deliver the baby during a public procession. Bullough comments on the many sources of this legend: The basic attitude is one of admiration for her success; moreover, her ultimate fall is explained in the stories as due to the reappearance of 'womanly weakness.' If she had managed to remain chaste and virginal, that is, more like a man, she would not have failed. (Cross Dressing 57) In non-sacred literature, Le Roman de Silence again serves as a good example, as the heroine Silence has to fight off numerous advances by the wife of her feudal lord, King Evan. The numerous threats to the body's integrity in Yde et Olive is but

${ }^{20}$ In this context, Christine de Pizan's "interpretation" of the lives of female saints in La Cité des Dames is noteworthy, as she consciously omits the physical aspects in the myths and replaces them with spiritual and intellectual ones. Of course, spirituality in Christine's work is understood as female, and not male (Cazelles 85). 
another example of that same phenomenon. Also, Yde's lament in line 7107 shows her desperation over being locked in her female body. She prays to God: "Glorious Dix, qui mains en Trinité, / De ceste lasse cor vous pregne pités" (Glorious Lord who lives in trinity, / Take pity on this wretched body).

Finally, the revelation of the body certainly figures as the climax in hagiographic narratives involving "monachopartenoi." Cazelles sees in the motif of revelation yet another emphasis on the corporal. In every Vita, such a forced exposure concludes the story, usually in the form of a public ordeal: "Invariably, the ordeal of female martyrs begins with a theatrical removal of the heroine's clothing, a scene that has no equivalent in the Passions that commemorate male saints" (52). Equally, Yde's exposure happens in public in the presence of the king's entourage: Li rois a tout son barnage mandé, / Devant aus tous ceste cose a conté / Tout em plourant a cascun escrié: / 'Seigneur,' dist il, ‘quel conseil me donrés?' / 'Fais les ardoir,' cascuns li a crié.

(The king asked for his baronage / He told the whole story in front of all of them; / Weeping, he cried out to them: / 'Sirs,' he said, 'What advice shall you give me?' / 'Have them burn,' each of them cried to him.) (v. 7255 7259)

The Yde et Olive poet plays with the motif by raising the expectation of the medieval reader who certainly would have been familiar with the traditional hagiographic version of such revelations. Instead, Yde is transformed into a real man. While this gender transformation is in large parts connected to ideas found in the hagiographic 
tradition, the basic theme of transformation can also be explored in a broader Christian context.

\section{The wider significance of transformation in Yde et Olive}

Christian faith is permeated with mystery and miracles, and maybe one of its most mystical aspects can be found in the miracle of the Eucharist: in the process of transubstantiation, bread and wine is transformed into the body and blood of Christ during the administering of the holy sacraments. Based on Scriptural sources of the Last Supper, the dogma of the Eucharist stands as a centerpiece of Catholicism, teaching that hidden in the form of the Eucharist, Jesus delivers himself to his mother, the Church, who then nurtures spiritually her faithful children through his divine essence. The idea of transformation figures as a central aspect of Christian doctrine, and in a society, in which people were used to "witnessing" God's power in every-day life, this miraculous aspect of faith must have had even more importance than today. Moreover, the first Canon of the Fourth Lateran Council of 1215 actually established a decree that reaffirmed officially the doctrine of transubstantiation. This importance of transformation for the medieval mind becomes obvious when looking at literature from the period. Containing some of the most beautiful images found in texts of the Middle Ages altogether, the Anglo-Saxon poem Dream of the Rood evolves around the theme of transformation in the form of a dream vision. The poem follows the gradual transformation of Christ's cross that found its origin in a regular tree and underwent its journey as a gallows to become an 
instrument of salvation, a sign of victory over death and finally a sacramental sign.

The imagery of the Rood takes on many shapes and forms, some of which seem almost contradictory, thus pointing to the transforming power within it. The speaker describes:

The Ruler's tree was worthily adorned / With gems; yet I could see beyond that gold / The ancient strife of wretched men, when first / Upon its right side it began to bleed. / I was all moved with sorrows, and afraid / At the fair sight. I saw that lively beacon / Changing its clothes and hues; sometimes it was / Bedewed with blood and drenched with flowing gore, / At other times it was bedecked with treasure. (in Hamer 161)

The looking "beyond" the gold to find the blood, not only points to the many stages of transformation in the cross, but also exemplifies medieval literary criticism that sought to uncover the many layers in a text (Irvine 55). The subject matter of the poem thus fits well into the tradition of glossing, of commentaries on Scriptural truth. Equally, the theme of transformation in Yde et Olive fits well into this tradition, not only when seen in the context of an ascension to male spirituality, but also as a typical product of a faith based on teachings that centered around transformation.

Yet another important form of transformation in the Christian religion can be found in the rite of baptism. As the next section will show, in Yde et Olive, baptism and transformation are closely linked with each other. In his study on medieval transvestite saints, Anson makes an interesting observance about an early Christian 
cult that associated baptism with androgyny: "Whatever the ceremony, it is clear that baptism rites among the Valentinians as well as among the Naassenes employed an elaborate symbolism of bisexual fusion and the transformation of female into male ..." (9). Clearly, androgyny is an important characteristic of Yde's persona as well. It is therefore necessary to explore these androgynous elements before turning to the significance of baptism in the poem.

\section{Yde's androgyny in the context of her transformation}

The figure of Yde seems to start out as and remain an androgynous form until the final transformation, for even before she changes into male clothing, her body does not seem to be wholly female. It is significant for the plot that the first detailed description of Yde's body happens right before King Florent's announcement of his intentions to marry her, an announcement which will eventually force her to "become male," important because that description remains somewhat ambiguous, especially in terms of her female qualities: "Jovenete est de .xv. ans tous entiers, / N'ot mamelete, c'on aperchoive riens" (She is a young woman of full fifteen years, / She has no breasts of which one takes any notice) $(6520-6521)$. The composition of these two lines underlines the ambiguity of her persona by describing her as a young woman, while clearly stating that her female development is lacking in a physical sense. Florent's threat of incest then pushes her shortly after that to suppress her female qualities even more. De Weever points further to the ambiguous use of vocabulary when describing Yde's body. Yde's face is white as 
snow, her lips are red as a rosebush, and her blond hair more precious than gold (lines 6505-6510), all colors that are typical for the portrait of a medieval Lady. However, the poet also uses elements that are usually reserved for a knight when describing her curly hair: "Les caviax blonds, qui cercelent arrier" (She had blond hair that curled in the back) (v. 6509). As De Weever points out, the same incongruities found in Yde's portrait also define the portraiture in the text Aucassin et Nicolette, in which the Saracen heroine Nicolette disguises herself as a minstrel to be reunited with her lover in France: "Ele avoit les caviax blons et menus recercelés" (in De Weever 375). The androgynous aspects of Yde's persona become the most obvious in the battle scenes, in which the poet describes Yde's manliness while addressing her as "Lady Yde" or "the beautiful one." During her fight with the thief, he states: "Damoiselle Yde tint par grant hardement / Entre ses bras le fort larron pullent" (Lady Yde held quite courageously / The strong, vile thief between her arms) (v. 6784-6785). During the fight against the Spanish to save King Oton's reign, Yde leads the Roman army:

.I. Espaignot feri qu'ele encontra / Que son escu li rompi et quassa / Et de son dos le hauberc li faussa; / Parmi le cors la lance li bouta, / Si l'abati: ains puis n'en releva. / Yde la bele sa lance resaca. / Ains mais sor home a nul jour ne hurta : / Petit sot d'armes, arriere retourna.

(She struck a Spaniard whom she met / So that his shield broke and shattered / And from behind, she pierced off his armor, / She forced the lance into his back, / And struck him down: Never again will he get up. / Yde the beautiful 
took back her lance, / Never before on any day had she struck down a man: /

She knew little of arms, she turned around.) (v. 6654-6661)

The juxtaposition of her courage in battle with her "lack of knowledge" in arms underlines her androgynous state between female and male. De Weever also points to the ambiguous use of the feminine pronoun "ele" to describe Yde in a text where "she" is anything but female (387). Moreover, in her editorial remarks on the poem, Brewka points out how the poet seems to switch from using the name "Yde" to the name "Ydé" after the heroine's transformation. Names always play a significant role in literature from the period, and name changes are a popular device in stories with gender plays to designate the inner change of the protagonist. Again, Le Roman de Silence serves well to illustrate the point: Silence's parents change their daughter's name from Silentia to Silentius after disguising her as a son, and at the end of the romance, when Silence takes on her female role, the text reiterates:

Silence atornent come feme. / Segnor, que vos diroie plus? / Ains ot a non Scilensiüs: / Ostés est -us, mis i est -a / Si est només Scilentiä"

(They dressed Silence as a woman. / Lords, what more can I say? / Once he was called Silentius: / they removed the -us, added an -a, / And so she was called Silentia.) (v. $6664-6668)$

The same idea is already present in Ovid's original story of Iphis. The mother rejoices at the choice of name for her daughter because it is ambiguous in gender: "The dazzled husband chose a name, his father's, / The family name of Iphis, neutral gender, / Which gave the pious mother pure delight, / And made her feel the name 
was not a lie" (266-7). Scanning through Yde et Olive, the poet is not consistent with the name change, which again, adds to the ambiguity of Yde's persona. However, there is a general tendency that the name is used with an emphasis on the final -e towards the end of the text, in various forms, for example Ydé, Ydee or Ydes. More importantly, in the following sequel of the cycle where Yde reappears, the name is consistently changed to Ydé. Walter makes a nice observation when she comments on Yde's response to the German soldier's question as to who she was: "Comment as non? A moi n'en choile ja. / 'J'ai non Ydes,' cele respondu a” (What is your name? Do not hide it from me. / 'My name is Ydé,' that one answered) (v. 6622 6623). Walter uses the sentence "J'ai non Ydes" to make a word play, translating it as "I have no idea" to point to Yde's ambiguous identity (313). Of course, in Old French "non" is "nom," but Walter's word play still illustrates well Yde's identity in between the two genders. ${ }^{21}$

The concept of androgyny plays a part in many different cultures, particularly in Eastern religions, such as in Hinduism:

One of the major teachings of Hinduism is that every man and woman contained within himself or herself both male and female principles. This maleness or femaleness remained in conflict within the individual and could only be harmonized for very brief periods during sexual intercourse, something which allowed the couple to realize the absolute. Such a

\footnotetext{
${ }^{21}$ Perret interprets Yde's name change from Yde to Ydé as a change from the female body to the male idea, "idée" (313).
} 
realization occurred when each had lost consciousness of his or her own sex and found the other. (Bullough 7)

Similarly, the Chinese concept of Yin and Yang plays with that idea. However, while it is well possible that these religions influenced medieval Europe, we can find examples of androgyny also in Greek and early Christian thought, which pertains much more directly to this study. The third-century philosopher Plotinus may serve best to illustrate Greek thinking for this context. As the founder of Neoplatonism, his thought views "multiplicity" as a problem and strives for what he calls the unification with "the One:"

... One must bring the vision within and see no longer in that mode of separation but as we know ourselves ... This conversion brings gain: at the first stage, that of separation, a man is aware of self; but retreating inwards, he becomes possessor of all: he puts sense away behind him in dread of the separated life and becomes one in the Divine; if he plans to see separation, he sets himself outside. (Fifth Ennead, in Leitch, et al. 183)

The basic notion of "difference" or separation figures as one of the most recurring discussions in literature, especially so in twentieth-century literary criticism with critics, such as Saussure and Derrida. For this study, the thoughts of Woolf and De Beauvoir fit especially well as they both apply the notion of difference to gender issues. In A Room of One's Own, Woolf introduces the notion of androgyny in her writing. In her view, gender consciousness destroys literature because the author 
cannot move beyond the fixation of the "I." She asserts that true creation can only happen beyond the binary opposites of male and female:

The normal and comfortable state of being is that when the two live in harmony together, spiritually cooperating. If one is a man, still the woman part of the brain must have effect, and a woman also must have intercourse with the man in her. (in Leitch, et al. 1025)

Although this seems to be outside the scope of this essay at first, it offers an alternative of how androgyny can be understood in Yde et Olive; that is, as an erasing of gender difference, which allows Yde to approach God, or the "One" in a Neoplatonist sense. In the process of her transformation to "becoming male," she hovers in an androgynous state that leads her towards spiritual growth. Reaching a state of androgyny then relates to acquiring special powers in the search for human perfection. ${ }^{22}$ Going back to the Christian context, Castelli notes that St. Paul suggests in Galatians 3:28 that becoming Christian erases difference: "There is neither Jew nor Greek, there is neither slave nor free man, there is neither male nor female; for you are all one in Christ Jesus." As already shown, Paul's notion that gender distinctions are not important before Christ is interpreted and expressed with the idea that everybody should strive to become "male" with later medieval thinkers. However, even infused with this gender-biased notion, the basic idea remains the

${ }^{22}$ Pointing to this same idea, Bullough reminds us of three Greek heroes that are known to have cross-dressed as women, assuming androgynous states that seem to have given them special powers: Achilles, Heracles and Theseus were the only ones to fight the Amazons successfully (Cross Dressing 31). 
same: "in all these situations, gender distinction is seen as a characteristic of the fallen status of human beings, one undone by redemption" (Castelli 30).

\section{The motif of baptism in Yde et Olive}

As mentioned, early Christian cults associated baptism with androgyny.

Baptism probably represents the most important step in Christian conversion, and again, the writings of Paul serve well to illustrate how it relates to the present subject. Hotchkiss explains:

In Paul's letter to the Galatians 3:27, baptism is described as 'putting on Christ' ... The Pauline metaphor appears to have been incorporated into the earliest baptismal ceremonies in the removal of clothing and, after immersion, the putting on of new white robes, apparently the same for men and women. (20)

The early Christian legend of Thecla serves as a good illustration of this thought: the pagan maid is so moved by the preaching of St. Paul that she decides to become Christian. After baptizing herself, she cuts her hair and dresses as a man (Anson 6). The Life of St. Abban serves as another useful example. In it, Abban baptizes the king's only child, a daughter: "Abban took the infant in his hands, and prayed earnestly to God that the king might have an heir; and the girl that he immersed in the font he took out as a boy, and laid it in the king's bosom. 'Here is thy son,' he said" (in Bullough, Cross Dressing 60). 
In Christian writing, baptism is connected with "becoming male," and it plays an equally important role in Yde's development from female to male. De Weever makes a strong argument for the presence of baths in connection with Yde's transformation; that is, she demonstrates that each important step in Yde's transformation is preceded by a bath (382). The poem starts by relating Yde's actual baptism, sign for her joining the Christian community: "Yde ot a non quant en fons fu levee" (Yde was her given name when she was lifted over the baptismal font) (v. 6292). Fifteen years later, she takes another bath, the bath that Florent draws for her to get ready to marry him. It is out of that bath that she escapes, disguised as a man:

Et la pucelle est fors du baing salie; / Dras d'omme vest, de riens ne s'i detrie: / En guize d'omme s'est bien aparillie.

(And the maiden jumps out of the bath; / She puts on men's clothing, she does not hesitate with anything: / She disguises herself well as a man.) (v. $6561-6563)$

Just as Thecla, she dons male clothing after her bath, which figures as her first step to "maleness." Finally, at the very end, King Oton forces her to take a bath to prove her identity:

.I. baing fait faire en la sale pavee; / Dedens entra, puis a Yde mandee, / Et elle I vint: li roi l'a commandee. / Despoulliés vous sans point de demoree: / Venés o moi baignier, ensi m'agree. 
(He had a bath drawn in the great hall; / He entered it, then he called for Yde, / And she came as the king had asked for her. / Undress yourself without delay: / Come and have a bath with me, it is my wish.) (v. $7242-7246$ ) It is during this last bath scene that Yde's transformation will become complete. De Weever comments: “Ide's baths become initiations into different ways of life in each case, just as her baptism as an infant signifies her initiation into the Christian life" (382).

However, the idea of baptism in Yde et Olive can be developed much further than De Weever has done. Sources show that early baptism rites consisted of the following steps: "instruction, apostaxis (rejection of Satan), syntaxis (profession of faith), disrobing, immersion, anointing, and symbolic robing” (Hotchkiss 21). These steps become important in the discussion of Yde et Olive, as her entire development can be read against this one initiation rite: The first step of instruction is clearly emphasized in the poem:

A ses .vij. ans fu a la letter mise: / Ele aprent tant, bien sot son sautier lire / Et en rommans et en latin escrire. / Bien ait li cuers qui si bien le doctrine. (At the age of seven, she was instructed in reading: / She learned well, knew well how to read her psalter / And how to write in Romance and Latin. / Indeed, anyone who is so well taught has a good heart.) $(6354-6357)$ Yde is well instructed not only in letters but also in Christian matters, as she repeatedly proves by her actions. Apostaxis, or rejection of Satan as second step in early baptismal rites, is represented by the threat of incest from her father, as well as 
by the thieves' offer to join their band, both events in Yde's life that try to bring her off the right path, that are temptations of evil, which she firmly rejects. She escapes her father and fights the thieves all-out. In the discussion on hagiography, this motif of temptation has already been discussed. Moreover, Paul's writings make a connection with "flight from evil" and baptism in 1 Corinthians 10 , where the flight of the Israelites out of Egypt is compared to baptism:

For I do not want you to be ignorant of the fact, brothers, that our forefathers were all under the cloud and that they all passed through the sea. They were all baptized into Moses in the cloud and in the sea. They all ate the same spiritual food and drank the same spiritual drink; for they drank from the spiritual rock that accompanied them, and that rock was Christ.

Just as the Israelites escaped their oppressors in Egypt, Yde escapes her oppressing father. The next step is Syntaxis, or the profession of faith, which happens repeatedly in the poem and is reaffirmed more strongly with every new trial. The more complicated her situation becomes, the more she places her trust fully in God: "Si face Dix de moi sa volenté" (And may God do with me as he wishes) (v. 7129). The disrobing and immersion happens symbolically when Yde is forced to take a bath with King Oton. The rite of anointing traditionally serves to give spiritual aid and comfort. In Yde et Olive, this step is naturally represented by the angel, who comes to Yde's assistance in a time of need. Based on the notion of "the anointing of the sick," this idea could even be developed further by saying that Yde's body 
needs anointing to be "cured," that is, to become male. After all, Yde does feign an "illness" during her wedding night. She tells her wife:

Car jou l'arai mout griés si com jou bee: / Jou ai .j. mal dont j'ai ciere tourblee.

(I will have you with much distress although I long for you: / For I have an illness which troubles me deeply.) $(7169-7170)^{23}$

Finally, the symbolic robing happens when Yde takes on her new male form. The parallels between early baptismal rites and Yde's story as a whole becomes particularly convincing when seen against the interpretation of the Ovide moralisé, discussed in chapter one, that sees Iphis as possessing a sinful soul. As shown, the original Ovidian plot is interpreted as evolving around the purging of that sinful soul: Mais quand nostre Mère Saincte Eglise catholique a receü en son giron la creature, elle prie Dieu pour elle par chacun jour devotement ce qu'il luy plaise donner cognoissance et voulenté de delaisser ses pechiez, de soy amender, repentir, confesser veritablement ...

(But when our mother, the Holy Church received in her bosom the creature, she prayed to God for her every day in great devotion, so that it would please him to give her knowledge and the will to let go of her sins, to amend herself, to repent, to truly confess ...) (253, my translation, my emphasis)

Baptismal rites were believed to purge all sins. In fact, often, baptism was put off until right before death so that the soul could enter Heaven without any stain.

\footnotetext{
${ }^{23}$ Walter connects this "illness" of Yde's body with Aristotle's notion of female as a deformity (319).
} 
Yde's development from the female body to the male soul, the androgynous elements in her persona bringing her closer to God, as well as the overall structure of the plot as seen against baptismal rites all point to the same theme: the cleansing of the soul. In this context, Yde's development fits right in with the allegorical adaptation of the Ovidian myth that focuses on the purging of sins. 


\section{CONCLUSIONS: GENDER PLAY IN MEDIEVAL CROSS-DRESSING}

The main goal of this essay was to show the significance of Yde's development in a religious and philosophical sense, seen in an allegorical context and its connection to the tradition of glossing ancient texts. Up to now, this study deliberately left out the sociological issues raised in the text, as they do not contribute directly to the argument. However, they play a useful role in placing the poem into the wider context of the motif of cross-dressing in medieval literature. Christine de Pizan takes the notion of "becoming male" and uses it in Le Livre de la Mutacion de Fortune to illustrate her own biography. In fact, this text is particularly worth mentioning because in it, Christine uses the same mythical figure of Iphis to describe her own transformation after her husband's death (Blumenfeld-Kosinski, City of Scholars 8). She describes how she was forced to become male by Fortune:

Or est il temps que je raconte $/ \ldots$ / Comment de femme homme devins, $/ \ldots$ / a parler selon methafore.

(Now it is time that I tell / ... / How I transformed from a woman in to a man, / . . / speaking metaphorically.) (v. 1025 - 1033)

She then goes on to retell Ovid's Iphis and Ianthe before describing her own change, effected by Fortune: "Transmuee me senti toute. / Mes membres senti trop plus fors 
/ Qu'ainçois .... " (I felt completely changed. / My limbs felt heavier than before. . .) $(1336-1337){ }^{24}$ Of course, Christine will not stay "male" for the rest of her life like Yde, as Kosinski-Blumenfeld rightfully points out: “. . . in the Livre de la Cité des Dames (1405) she will become a 'woman' again, defined by a 'woman's work' which in that case will be writing not spinning" (The City of Scholars 6). Christine's work serves as a nice transition to the wider discussion of cross-dressing in the Middle Ages, as it points away from the strictly hagiographic interpretation of this study to a socially critical discussion around gender play.

As mentioned briefly in the introduction, maybe the most typical and widespread instances of cross-dressing in literature of the period happen in the fabliaux. However, the use of the motif in these instances differs significantly from Yde et Olive. Yde becomes a man in a context of virtue and spiritual development, and not to fulfill some hidden agenda of power or dominance; that is, her character is never described as wanting to equalize somehow the power relations between women and men. Of course, the text as a whole certainly raises these issues, but the heroine as a person does not seem to have ulterior motives in that respect. Her fate simply pushes her to act the way she does, and due to her virtue, she succeeds in her endeavors. In contrast to Yde, the typical heroine of the fabliaux usually crossdresses to consciously exert power over men. De Berangier au lonc cul (Bérangier of the Long Ass) illustrates well the vindictive nature of the female character in the fabliaux. In the story, a "purely bred" daughter is forced to marry a man without

${ }^{24}$ This translation is taken from Blumenfeld-Kosinksi in City of Scholars, 9. 
honor due to her father's debts. A lazy coward by nature, the husband takes off in his armor every day, pretending to go out and defeat his enemies. Instead, he sits in the nearby forest all day and beats up his own shield to keep up appearances. The wife soon gets suspicious and one day, she dresses as a knight and follows him. When she sees what a coward he is, she confronts him in her disguise and forces him to choose either to fight her or to "kiss her ass." Of course, her husband chooses the latter, and to underline his stupidity, the text comments on the fact that he does not realize that he actually kisses her female genitals instead, hence the title of the fabliau. The wife then goes home and humiliates her husband further by choosing a new lover and forcing her husband to watch:

Desconfit se sent et maté; / Et cele fait sa volonté, / Qui ne fut sote ne vilaine: / A mol pastor chie lox laine.

(He felt checkmated. He felt ill. / And from that day on, she did her will: / She was no common girl or fool. / When the shepherd's weak, the wolf shits wool). (in Du Val, v. 297-300)

The moral is stated quite clearly at the end. Due to the husband's weakness, his wife does what she wants. Of course, the woman is the clear winner in the tale, and of course, the husband is rightfully humiliated because he has no prowess or virtue in him, but nevertheless, the woman is not depicted in a favorable light. Her crossdressing does not serve to accomplish an honorable deed, but a rather base one. While the reader clearly stands on her side and feels for her situation as an unhappy 
wife, her actions are not described positively, and the moral really teaches husbands to take more charge, which is typical of the fabliaux.

Whereas the cross-dressed woman exerts a certain power over the men in these stories, this newly found power is never portrayed in a positive light. It rather helps to underline the misogynist tone of the stories by showing the immoral and deceitful character of the woman in disguise. Similarly, the numerous instances of men who cross-dress in literature never serve to show the hero in an exceptionally good light. The man in disguise is not depicted as hero, does not advance his character or accomplish something meaningful by it. Szkilnik comments: "There might be at least one point to which all the medieval writers would agree: it is not the same for a man to dress as a woman as for a woman to dress as a man ... For a man, to dress as a woman is to debase himself" (62). In line with this reasoning, instances of male cross-dressing in medieval literature are kept short and mostly used for a comical effect.

All of these instances of cross-dressing differ from how the motif is used in Yde et Olive. At the beginning of this essay, I mentioned two other medieval works that treat female cross-dressing in an "epic" manner comparable to Yde's story: $L a$ chanson de Tristan de Nanteuil and Le Roman de Silence. In these instances, crossdressing serves a more "noble" end. The women do not intend to trick anybody with their disguise, but are actually forced to become men. Moreover, they succeed exceptionally well in their new roles and ascend to great fame. The plot development works quite nicely, as it excuses the heroine to act against the "norm," 
while also allowing her to develop her "maleness." But of course, even if the heroine in men's clothing gets praise for her great virtue, it is always only seen against that male virtue in her. Moreover, the heroine is eventually forced to surrender her "role" and return to the one assigned to her by nature, such as in $L e$ Roman de Silence. To move from the fictional realm to factual history, Joan of Arc, the famous virgin saint, might serve as a good example of what happens to a heroine who in fact refuses to take off her male clothing at the end of her "quest." Her story fits well into the present discussion as a real-life version of the transvestite saint. Joan attains her sainthood by denying her femaleness, and in line with hagiographic texts, her cross-dressing brings about something significant for the entire community: She saves France. However, Joan's fault lies in her refusal to accept her "natural" role after the completion of her quest. She refuses to take off her male clothes, a mistake that brings about her execution (De Weever 389). In Le Roman de Silence, the heroine marries the king, in Yde et Olive, the heroine becomes a man, but in the real world of Joan, the societal order cannot be established so smoothly as in fiction. The authorities have to actually kill her to reestablish balance in real life. Polysemous in its nature, cross-dressing always remains an ambiguous discussion topic among medievalists. The central dilemma lies in the fact that these instances of gender blurring can be read in two basic ways. In line with traditional criticism, the cross-dressed heroine really serves to reaffirm the male paradigm, as she only succeeds by assuming a male role, and not by asserting her femininity. Yde only attains a higher state by suppressing her femininity, which makes this poem yet 
another propaganda piece for male hegemony. Recent criticism, however, has examined cross-dressing by focusing mainly on the destabilizing factor of such gender plays to the societal order, even if this destabilization happens only for a limited time within a particular narrative. Yde succeeds because she dresses as a man, but she also succeeds more than any other man: she becomes head of the Roman army, liberates the kingdom and marries the king's daughter, uniting her own reign of Aragon with that of Rome. Yde does not just become a regular hero, but an exceptional one. Moreover, she seems to act so well in her new role, that nobody suspects that something might be wrong until she is forced to perform during the wedding night. As long as she can stay asexual, she does not meet any obstacles, which is interesting when seen against medieval philosophy on gender. The previous chapter has already shown how the feminine was firmly connected with the corporal. Clerics warned against woman as being the sexual one, the physical one, who poses a threat to the spiritual state of man. One of the most popular works on which medieval clerics based their misogynist arguments was The Golden Book of Marriage by Theophrastus, a Greek philosopher from the third century B.C. He warns against the distraction of women: "A wise man therefore must not take a wife. For in the first place his study of philosophy will be hindered, and it is impossible for anyone to attend to his books and his wife" (in Miller 412). In the tradition of Theophrastus, the early thirteenth-century Walter Map makes his case against marriage by listing famous men who cast off women to devote themselves to study: "Cicero, after the divorce of Terentia, was unwilling to marry, professing himself 
unable to give his attention at once to a wife and to philosophy" (in Miller 441). Maybe most famously, Abelard deplores the corrupting force of his love for Heloise who drives him away from his studies:

Most tedious was it for me to go to the school or to stay there; laborious likewise when I was keeping nightly vigils of love and daily of study. Which also so negligently and tepidly I now performed that I produced nothing from my mind but everything from memory; nor was I anything now save a reciter of things learned in the past .... (13)

After things are sorely out of control with Heloise being pregnant, Abelard reminds the reader of "the ruin to which even the greatest men, from the very beginning of the human race, [have] been brought down by women" (15).

Clerics clearly separated the idea of the male mind from the female body. However, in Yde's case, it is only when she has to perform with her body as a man that her real troubles start. At the prospect of the wedding, she laments her lack of "equipment" to perform for her wife. At the king's proposal to take his daughter, she goes into shock:

Yde l'entent, li sans li est müés: / Ne set comment se porra demener, / N'a member nul qu'a li puist abiter. / Nostre Seignour a sovent reclamé: /

Glorous Dix, qui mains en Trinité, / De ceste lasse cor vous pregne pités. (Yde heard him and her blood froze. / She did not know how to act; / She did not have any member with which she could copulate. / Many times, she 
called upon the Lord: / Glorious Lord, who lives in trinity, / Take pity on this wretched body.) (v. $7102-7107)$

For the first time since she took on her new role, Yde does not know how to act. That is, so far she exceeded in the role as a man in any respect, but it is exactly the physical that is now holding her back from fulfilling her role as a man. The physical aspect that is usually related to the feminine remains the only obstacle to her maleness. Therefore, God needs to "fix" this one thing that Yde cannot appropriate herself, whereas in any other respect, she has already become a man. The text clearly draws a dividing line between the male biological "sex" and the male "gender" in a social sense. This raises the question of what constitutes maleness in society, a question that has stood in the center of feminist criticism since Judith Butler's study on gender. In her works, she equals gender with performativity; that is, being a man depends on what one does in a social context, how one acts, what role one assumes, and not what one is. In other words, gender is a social construct that finds its origin in cultural institutions and discourses: "There is no gender identity behind the expressions of gender; that identity is performatively constituted by the very 'expressions' that are said to be its results" (Gender Trouble 25). Yde takes on the male gender long before ultimately taking on the male sex by an act of God. Her environment views her as a man because of who she is socially, and not what she is biologically. Yde assumes her role as a knight and follows the set of rules that come with such an "assignment." Completely modeling the role of the 
knight in courtly romance, she frees the Roman kingdom and wins the favors of a lady:

Les uns a mors et les autres navrés / Et s'en a tant em prison amenés / Qu'il aquita la terre et le regné. / La fille au roi l'a si fort enamé / Qu'ele li dist ne li pot plus celer.

(He killed the ones and drowned the others / And he brought so many to prison / That he freed the land and the kingdom. / The king's daughter loved him so much / That she told him - she could not hide it any longer from him.) (v. $7043-7047)$

Nobody suspects anything, and Yde naturally follows her duties as a knight, even when the situation becomes more precarious. At the wedding proposal, she first hesitates and attempts to change the king's mind, but then she realizes her mistake:

Comment qu'il voist, malvais plait ai tourné; / Et nonpourquant jou ai dit fausseté. / Puis que j'ai Romme et l'onour conquesté, / J'espouserai la fille au couronné.

(However one looks at it, I am entangled in a bad affair; / And in any case, I have deceived. / Since I won over Rome and honor, / I will marry the daughter of the crowned one.) (v. $7125-7128)$.

She knows that as long as she plays the role attributed to a knight, she will be safe. Her male disguise results in her male identity that involves getting "tangible signs of achievements": a woman and an empire (de Weever 381). In the same way, Olive assumes the role of the dutiful wife even after she finds out Yde's real identity 
(Walter 319). She stands by her "husband's" side no matter what will happen to $\operatorname{him} /$ her:

Mais or soiés toute rasseüree: / Puis que vous estes pour loiauté gardee, / Ensamble o vour prendrai ma destinee.

(Henceforth you shall be completely reassured: / For you are protected in loyalty, / I will take my destiny together with you.) (v. $7221-7223$ ) The couple plays their role according to the romance paradigm despite the little obstacle between them, which gives the entire plot a nice little twist at the end.

Clearly, the Yde et Olive poet plays with gender roles and even goes as far as allowing himself not to state clearly what really did happen during that ominous wedding night. The text stays somewhat ambiguous in describing what goes on in the chamber between the newly-weds. Yde feigns an illness, and Olive agrees to delay things until the wedding party has left:

Dont ont l'un l'autre baisie et accollee; / En cele nuit n'i ot cri ne mellee. / La nuis passa, si revint la journee.

(Thus, they kissed and hugged each other; / In that night, there was no cry nor skirmish. / The night passed, and the day returned.) (v. $7190-7191$ ) However, at this point, Yde's character is already so well developed that the reader does not doubt her integrity anymore. The poet has clearly established that the heroine does not have a different choice but to follow through with what she was forced to do due to her father's indiscretion. The possibility of Yde doing the "unspeakable" act does not seem to be a big issue, but rather a liberty on the poet's 
part to push the gender play yet another step further, while always staying firmly on his track to develop Yde's character as a hero/heroine. However, it becomes clear that something must happen to resolve that one last obstacle that holds Yde back from really becoming the saintly hero she aspires to be. Mounsey's comments on an essay by Davidson on the theme of sex change in the original Ovidian text Iphis and Ianthe fits well into the present discussion:

... 'Unnatural' sexual acts, those that occur without a penetrating penis, must be deemed impossible, even at the expense of allowing a magical, though equally impossible, change of sex of Iphis from female to male in order that the marriage be consummated 'normally.' The result of political discourse, therefore, is that sex may be considered unstable to maintain the stability of gender 'norms' so that they may become the loci of ideological enforcement. (20)

This holds also true for Yde et Olive, as the text does not really challenge gender roles, but reestablishes firm categories at the end. However, at the same time, the reader cannot erase what has happened in the 1500 preceding lines, which certainly adds a subversive element to the text. The whole subject is a tricky one and stays as ambiguous as Yde's persona, which seems to reinforce gender difference because her moral development is clearly connected with becoming male, but it also undercuts the notion of gender categories because she succeeds in taking on a male role as a woman without having any problems at all except for a biological one. This ambiguous treatment of gender is typical for the thirteenth century, as Szkilnik points 
out. Poets seem to have a special liking for gender play during that specific period, even touching on the possibilities of homosexuality, as in Yde's bed scene on the wedding night, but they quickly move away from this ambiguous style in the late fourteenth and fifteenth centuries only to fall back into the traditional openly misogynist style:

It is as if medieval writers, at first interested in trying out different combinations, had later become scared by the consequences of their boldness, scared by the ease with which their heroines were undertaking male tasks and being too good at them, scared by the troubled waters they had stirred by touching on the sensitive topic of homosexuality. It was much more comfortable to fall back on prejudices and to treat cross-dressing as yet another female trick, though a purely practical one that would not jeopardize the fundamental distinction of the sexes. (82)

In Yde et Olive, this ambiguity still exists in the course of the plot and is not resolved until the very end. The discussion on gender could be developed much further, but those gender and sociological questions would exceed the focus of this study. To bring it back to the present discussion, some aspects of cross-dressing in the poem certainly do challenge the basic social construct of the time, but they are followed by the firm establishment of the "normal order" of things, reaffirming the male paradigm of the saintly hero. It is as if the writer wanted to create female heroism to a certain extent, but could not step beyond the male construct of heroism (Hotchkiss 127). 
I chose to focus less on strictly sociological issues raised by the text, which seems to be the current trend in medieval criticism, but instead to focus on what might be a more literary aspect of the poem by trying to place it within the tradition of translatio. Seen against the backdrop of medieval practices of text production, the story of Yde becomes an example of how the Latin tradition and knowledge was transferred to France and used in the context of its time to teach a lesson. Seen in the context of hagiography, it ultimately takes on an allegorical function. If Yde's transformation is seen as an ascension from the female body to the "male soul" in hagiographic terms, its basic message does not differ much from the Ovide moralisé, which transformed the Latin fable into a Christian parable. Yde's story transmits a moral message to the reader, a typical device of medieval writers. The text first establishes a solid ground on which the lesson can be built by describing the dangers posed to society in the form of incest and disrupted gender relations. It then proceeds to use Yde's transformation to bring order back to society. In a literal sense, it reestablishes societal order in the plot, when Yde secures the family line of Aragon and Rome. In an allegorical sense, it reaffirms spiritual order by showing Yde's development as gradual ascension to a purified state in the tradition of hagiography. The poem first prepared the "fertile ground," in Chrétien's words, on which the moral lesson took a solid hold and bore fruit. Moreover, the theme of revelation in Yde's story is indicative of the revealing of the poem's ultimate lesson. Just as Yde's new male body is revealed under what was a female body in disguise, philosophical truth is revealed under the cloak of the poem inspired by an ancient 
pagan fable. Yde transforms into a higher state, just as the Ovidian myth is transformed to take on higher truth. In both instances, the existing old form is seen in a new light by lifting the veil off the hidden treasure. 
REFERENCES

\section{Works cited}

Alighieri, Dante. Il Convivio. Ed. Richard H. Lansing. New York: Garland, 1990.

Anson, John. "The Female Transvestite in Early Monasticism : The Origin and Development of a Motif." Viator 5 (1974): 1-32.

Bloch, R. Howard. Etymologies and Genealogies: A Literary Anthropology of the French Middle Ages. Chicago and London: The University of Chicago Press, 1983.

Bloch, R. Howard. The Scandal of the Fabliaux. Chicago and London: The University of Chicago Press, 1986.

Blumenfeld-Kosinski, Renate. "Christine de Pizan and Classical Mythology: Some Examples from the Mutacion de Fortune." The City of Scholars: New Approaches to Christine de Pizan. Ed. Margaret Zimmermann and Dina De Rentiis. European Cultures: Studies in Literature and the Arts. Ed. Walter Pape. Vol. 2. Berlin, New York: Walter de Gruyter, 1994. Pages 3-14.

---. Reading Myth: Classical Mythology and Its Interpretations in Medieval French Literature. Stanford: Stanford University Press, 1997.

Boswell, John. The Kindness of Strangers: The Abandonment of Children in Western Europe from Late Antiquity to the Renaissance. New York: Pantheon, 1988. 
Brewka, Barbara Anne, ed. "Esclarmonde, Clarisse et Florent, Yde et Olive I, Croissant, Yde et Olive II, Huon et les Géants, sequels to Huon de Bordeaux, As Contained in Turin ms. L. II. 14: An Edition." Diss. Vanderbild U, 1977.

Bullough, Vern L. and Bonnie Bullough. Cross Dressing, Sex and Gender. Philadelphia: University of Pennsylvania Press, 1993.

---. "Medieval Medical and Scientific Views of Women." Viator 4 (1973): 485502.

Burrow, J.A. Medieval Writers and Their Work: Middle English Literature and its background 1100-1500. Oxford: Oxford University Press, 1982.

Busby, Keith. "Plus acesmez qu'une popine: Male Cross-Dressing in Medieval French Narrative." Gender Transgressions: Crossing the Normative Barrier in Old French Literature. Ed. Karen J. Taylor. New York: Garland Publishing, 1998. Pages 45-59.

Butler, Judith. Gender Trouble: Feminism and the Subversion of Identity. New York: Routledge, 1990.

Cadden, Joan. Meanings of sex difference in the Middle Ages: Medicine, science, and culture. New York: Cambridge University Press, 1993.

Castelli, Elisabeth. "I Will Make Mary Male: Pieties of the Body and Gender Transformation of Christian Women in Late Antiquity." Body Guards. Ed. Julia Epstein and Kristina Straub. New York: Routledge, 1991. Pages $29-49$. 
Cazelles, Brigitte. The Lady as Saint: A Collection of French Hagiographic Romances of the Thirteenth Century. Philadelphia: University of Pennsylvania Press, 1991.

Christine de Pizan. Le Livre de la Mutacion de Fortune. Ed. Suzanne Solente. Société des Anciens Textes Français. Paris : Editions A. \& J. Picard \& Cie, 1959.

Clark, Robert L. A. “A Heroine's Sexual Itinerary: Incest Transvestism, and SameSex Marriage in Yde et Olive." Gender Transgressions: Crossing the Normative Barrier in Old French Literature. Ed. Karen J. Taylor. New York: Garland Publishing, 1998. Pages 89-105.

Davidson, Roberta. "Cross-Dressing in Medieval Romance." Textual Bodies: Changing Boundaries of Literary Representation. Ed. Lori Hope Lefkovitz. New York: State University of New York Press, 1997. Pages 59-74.

De Boer, C., ed. Ovide moralisé en prose. Amsterdam: North-Holland Publishing Company, 1954.

De Weever, Jacqueline. "The Lady, the Knight, and the Lover: Androgyny and Integration in La Chanson d'Yde et Olive." Romanic Review 82:4 (1991): 371-391.

Durling, Nancy Vine. "Rewriting Gender: Yde et Olive and Ovidian Myth." Romance Language Annual 1 (1989): 256-262.

Dutton, Paul Edward, ed. Carolingian Civilization: A Reader. Ontario, Canada: Broadview Press, 1999. 
Du Val, John and Raymond Eichmann, ed and trans. Cuckolds, Clerics and Countrymen: Medieval French Fabliaux. Fayetteville: The University of Arkansas Press, 1982.

Freeman, Michelle. "Problems in Romance Composition: Ovid, Chrétien de Troyes, and the Romance of the Rose." Romance Philology 30 (1976): 158-68.

Gravdal, Kathryn. "Confessing Incest: Legal Erasures and Literary Celebrations in Medieval France.” Comparative Literary Studies 32:2 (1995): 280-295.

--- "Incest in Medieval Literature and Society." Forum for Modern Language

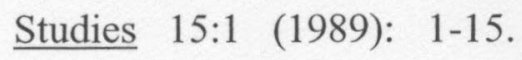

Hamer, Richard, ed. A Choice of Anglo-Saxon Verse. London: faber and faber, 1970.

Heldris De Cornuälle. Silence : A Thirteenth-century French Romance. Ed and trans. Sarah Roche-Mahdi. East Landing : Michigan State University Press, 1992.

Hotchkiss, Valerie R. Clothes Make the Man: Female Cross Dressing in Medieval Europe. The New Middle Ages. Ed. Bonnie Wheeler. New York: Garland Publishing, Inc., 1996.

Irvine, Martin. “Anglo-Saxon Literary Theory Exemplified in Old English Poems: Interpreting the Cross in The Dream of the Rood and Elene." Old English Shorter Poems: Basic Readings. Ed. Katherine O’Brien O’Keefe. New York and London: Garland Publishing, 1994. Pages 31-57. 
Kay, Sarah. The Chanson de Geste in the Age of Romance: Political fictions.

Oxford: Clarendon Press, 1995.

Knowles, David. The Evolution of Medieval Thought. Baltimore: Helicon Press, 1962.

Krause, Kathy M, ed. Reassessing the Heroine in Medieval French Literature. Gainesville, FL: University Press of Florida, 2001.

Leitch, Vincent B., ed. The Norton Anthology of Theory and Criticism. New York: W.W. Norton \& Company, 2001.

Lodge, Kristine Funch. “Aelfric's Material Girls: The Importance of the Female Body in Lives of Saints." M.A. Thesis. Wake Forest University, 2000. Marie de France. Fables. Ed and trans. Harriet Spiegel. Medieval Academy Reprints for Teaching. Ed. Madeline Caviness, et al. Toronto: University of Toronto Press, 1994.

---. Lais. Trans. Alexandre Micha. Paris : Flammarion, 1994.

Meisel Anthony C. and M.L. del Mastro, ed and trans. The Rule of St. Benedict. New York: Doubleday, 1975.

Miller, Robert, ed. Chaucer: Sources and Backgrounds. Oxford: Oxford University Press, 1977.

Moncrieff, C.K. Scott, ed. "The Calamities of Abelard." In: The Letters of

Abelard and Heloise. New York: Cooper Square Publishers, Inc., 1974.

Mounsey, Chris, ed. Presenting Gender: Changing Sex in Early-Modern Culture.

Lewisburg: Bucknell University Press, 2001. 
Perret, Michèle. "Travesties et Transsexuelles: Yde, Silence, Grisandole, Blanchandine." Romance Notes $25: 3$ (1985) : $328-340$.

Poirion, Daniel, ed. Chrétien de Troyes : Oeuvres completes. Littérature française du Moyen Age. Paris: Editions Gallimard, 1994.

Robinson, James M., ed. The Nag Hammadi Library. San Franciso: Harper \& Row, 1977.

Robinson, David Michael. “The Metamorphosis of Sex(uality): Ovid's "Iphis and Ianthe" in the Seventheenth and Eighteenth Centuries." Presenting Gender: Changing Sex in Early-Modern Culture. Ed. Chris Mounsey. Lewisburg: Bucknell University Press, 2001.

Sautman, Francesca Canadé. "What can they possibly do together? Queer epic performances in Tristan de Nanteuil." Same Sex Love and Desire Among Women in the Middle Ages. Ed. Francesca Canadé Sautman and Pamela Sheingorn. The New Middle Ages. Ed. Bonnie Wheeler. New York: Palgrave, 2001 .

Szkilnik, Michelle. "The Grammar of the Sexes in Medieval French Romance." Gender Transgressions: Crossing the Normative Barrier in Old French Literature. Ed. Karen J. Taylor. New York: Garland Publishing, 1998. Pages $61-88$.

The Bible Gateway. Gospel Communications International 1995-2002. Oct 15 2002. <http://www.gospelcom.net >. 
Thompson, Stith. Motif-Index of Folk-Literature. 6 Vols. Bloomington: Indiana UP, $\quad 1955-58$.

Walecka, Anna. "The Concept of Incest." Romance Language Annual 5 (1993): $117 \ldots$

Walter, Marguerite C. "Cross-Gender Transformation and the Female Body in $\mathrm{La}$ Chanson d'Yde et Olive." Mediaevalia 22:2 (1999): $307-322$.

Watt, Diane. Behaving Like a Man? Incest, Lesbian Desire, and Gender Play in Yde et Olive and its Adaptations. Comparative Literature 50:4 (1998): $265-285$.

White, Carolinne, ed and trans. Early Christian Lives. London: Penguin Books, 1998.

Wild, Gertraud. "Crossing Boundaries: Wilgefortis, the Transvestite Saint." M.A. Thesis. Arizona State U, 1997. 
Works consulted

Allen, Peter L. "The Ambiguity of Silence - Gender, Writing, and Le Roman de Silence." in: $\underline{\text { Sign, Sentence, Discourse - Language in Medieval Thought }}$ and Literature. Ed. Julian Wasserman. Syracuse: Syracuse University Press, 1989: $98-112$.

Bloch, Howard. "Silence and Holes : The Roman de Silence and the Art of the Trouvère." Yale French Studies 70 (1986): 81 - 99.

Bullough, Vern L. "On Being Male in the Middle Ages." in: Medieval Masculinites - Regarding Men in the Middle Ages. Ed. Clare A. Lees. Medieval Cultures Vol. 7. Minneapolis: University of Minnesota Press, 1994: $31-43$.

Boswell, John. The Marriage of Likeness: Same-Sex Unions in Pre-Modern Europe. London: HarperCollins Publishers, 1995.

Chickering, Howell D., ed and trans. Beowulf. New York: Anchor Books Doubleday, 1977.

Duby, Georges. Love and Marriage in the Middle Ages. Trans. Jane Dunnett. Mâle moyen age. Flammarion 1988. Chicago: The University of Chicago Press, 1994.

Gaunt, Simon. Gender and Genre in Medieval French Literature. Cambrigde Studies in French. Cambridge: Cambridge University Press, 1995. 
Gaunt, Simon. "Straight Minds/"Queer" Wishes in Old French Hagiography: La Vie de Sainte Euphrosine." Premodern Sexualities. Ed. Louise Fradenburg and Carla Freccero. New York, Routledge, 1996. Pages 153-173.

Kinoshita, Sharon. "Heldris de Cornuälle's Roman de Silence and the Feudal Politics of Lineage." PMLA 110:3 (May 1995): 397-409.

Labbie, Erin F. “The Specular Image of the Gender-Neutral Name: Naming Silence in Le Roman de Silence." Arthuriana 7:2 (Summer 97): 63-77.

Lasry, Anita Benaim. "The Ideal Heroine in Medieval Romances: A Quest for a Paradigm." Kentucky Romance Quarterly 32:2 (1985): 227-243.

McCracken, Peggy. "The Boy Who Was a Girl: Reading gender in the Roman de Silence.” Romanic Review 85:4 (Nov 1994): 517-536.

McLeod, Glenda. Virtue and Venom: Catalogues of Women from Antiquity to the Renaissance. Ann Arbor: The Unversity of Michigan Press, 1991.

New Advent. The Catholic Encyclopedia. Online Edition 1999. Oct 152002. $<$ http://www.newadvent.org $>$.

Saint Martin, Kimerly Ariane. "Radha-Krishna Cross-Dressing in Medieval Indian Painting, Poetry and Worship: A Multi-Leveled Metaphor." M.A. Thesis. University of California, 1992.

Shamkovitch, Tatyana Ivanova. "Saintly Hero: Mythological, Epic and Ecclesiastical Perspectives on the Image of the Saint in Medieval Hagiography." Diss. State University of New York, 1991. 
Stock, Lorraine Kochanske. "Arms and the (Wo)man in Medieval Romance: The Gendered Arming of Female Warriors in the Roman d'Eneas and Heldris's Roman de Silence." Arthuriana 5:4 (Winter 1995): 56-83.

---. "The Importance of Being Gender "Stable": Masculinity and Feminine Empowerment in Le Roman de Silence." Arthuriana 7:2 (Summer 1997): $7-34$

Watt, Diane. "Read my Lips: Clippyng and Kyssing in the Early Sixteenth Century." Queerly Phrased: Language, Gender, and Sexuality. Ed. Anna Livia and Kira Hall. New York: Oxford University Press, 1997. Pages 167-177. 
APPENDIX: THE SONG OF YDE AND OLIVE

I undertook this translation from the original Old French poem La chanson d'Yde et Olive for study purposes only. The following rendition of the poem is by no means an elegant solution, but should serve merely as a reference point to the present study. Please refer to the introduction of the essay for a wider context of the entire cycle, in which this poem occurs:

6222 Full of joy, Florent came to Aragon.

6223 The noble Garin laughed in his heart

6224 Over having peace and seeing Florent again.

6225 Both of them were glad, happy and joyous.

6226 They thanked God the almighty for it.

6227 With an abundance of riches,

6228 They rode handsomely to the palace;

6229 Happily, Clarisse went to meet them,

6230 And there were more than a hundred maidens

6231 With beautiful, happy and joyous hearts.

6232 Florent hugged her with his strong body, 
6233 And kissed her softly with a smile.

6234 Together, they went demurely to the monastery:

6235 Florent gave her a finely embroidered silk cloth

6236 And a marc of gold; and then others gave gifts;

6237 Then, they went to pray graciously.

6238 Once the good priest Clement had celebrated mass,

6239 They went to dinner without delay;

6240 They had many dishes, all much to their liking.

6241 After the meal, some of them entertained themselves:

6242 The children learned how to fence

6243 And most of them were playing backgammon.

6244 The minstrels were giving them a good time.

6245 The people of Aragon were happy

6246 That there was peace throughout the land.

6247 [But] King Garin was becoming weak,

6248 His beautiful face pale and shattered;

6249 In little time, he had become weak.

6250 Pleasure did not mean anything to him anymore

6251 Neither hunting nor the sparrow hawks' flight.

6252 The barons assembled around him:

6253 They sent for the doctors to assist them; 
6254 All of them said that nothing could be done for him

6255 And bitter death began to press him hard,

6256 And did not want to abandon him ever.

6257 He made his will, he wanted no delay:

6258 Everything he had, he left to God.

6259 May God have mercy and pity on his soul!

6260 His two hands joined, he looked towards Heaven;

6261 He appealed to God, the righteous Father:

6262 "Relieve me! I am in great distress.

6263 I want to leave the world with your permission,

6264 But one thing makes my heart happy,

6265 That my barons live in peace everywhere."

6266 He called clearly for his beloved child.

6267 "May God be with you, Florent. I let go of my kingdom.

6268 Pray to God that he may have pity on me."

6269 And he lied down and did not speak another word.

6270 The king died, the clergy came:

6271 They buried him that day in the monastery.

6272 The king died that day.

6273 Florent became king with prudent countenance,

6274 He wore the gold crown that month. 
6275 Clarisse was crowned as queen.

6276 They kept great pleasure in their lives.

6277 [So that] King Florent got his wife pregnant;

6278 The noble lady carried her child:

6279 [And] the time approached that she should deliver.

6280 She looked quite radiant and colored;

6281 [Yet] she was frightened by her pregnancy,

6282 She often called upon Saint Mary:

6283 "Assist, my lady, this weary and distraught woman

6284 So that she be delivered from her fruit!"

6285 The king listened closely to the queen;

6286 He came to the monastery with a big following:

6287 He prayed for the one that he loved so much,

6288 But there is no use: She will have little time left;

6289 Their great love will soon be separated:

6290 That she die; that was her unhappy fate.

6291 She had a daughter; she was carried to the monastery;

6292 Yde was her given name when she was lifted over the baptismal font.

6293 They showed his daughter to King Florent;

6294 When he saw her, he displayed great joy.

6295 Shortly thereafter, he asked for the queen. 
6296 Clearly, the situation could not be concealed,

6297 That's why they told him the truth.

6298 When the king heard and listened to it,

6299 He fell in a faint; such pain did he endure.

6300 As he rose again, he struck his hands.

6301 He came running to see his wife;

6302 Many of his people followed him.

6303 He came to the palace and found her dead,

6304 The one whom he had loved most in the world.

6305 He lifted his voice in the name of Clarisse:

6306 "Sister, sweet friend, alas that you were ever born!

6307 For you, I have left behind so many things

6308 And my flesh had found peace;

6309 Now my great pain is doubled because of you:

6310 It is clear that you have been taken from me."

6311 The tears ran down from his eyes:

6312 He cried and sighed with a sorrowful countenance,

6313 And his chest was completely soaked with tears;

6314 Then, he began falling backwards again. 
6315 Sorbarrés ${ }^{25}$ lifted him up at once

6316 And said: "Good king, in the name of your great virtue,

6317 Do you want to kill yourself with grief?"

6318 "God," Florent said, "My grief is doubled.

6319 Disloyal death, you have dared too much

6320 When you took away my wife!"

6321 The people around him were troubled;

6322 They mourned gently for their queen

6323 Until the morning when dawn appeared.

6324 Noble was the grief that was displayed for Clarisse:

6325 They cried and screamed and endured great suffering:

6326 They did not stop until they reached the monastery;

6327 There were many knights with them:

6328 Everybody was crying for the queen.

6329 After mass, as soon as it was completed,

6330 They enclosed Clarisse in a coffin;

6331 They interred the beautiful one in the chancel.

6332 The clergy was assembled all around

6333 The king returned to his great old hall,

${ }^{25}$ Sorbarrés appears in a previous episode of the poem. He is former King of Catalonia who helps Clarisse and Florent. Upon realizing the power of God, he joins them on their way home to Aragon. 
6334 From where he lamented his grief doubled by the queen

6335 "What will become of me," he said "Because of you, my dear?"

6336 Sorbarrés had his daughter brought to him immediately;

6337 Upon seeing her, he cried out loudly:

6338 "Sweet friend, now you are an orphan."

6339 And the men said: "You commit a shameful deed:

6340 By showing grief you will not have her back again.

6341 Let go of your grief, and you will behave in a courtly manner.

6342 You have a beautiful daughter from her;

6343 There is none so fair as far as the Greek sea.

6344 For suich compensation, let go of this commotion!

6345 The king responded: "Sirs, indeed, I accept;

6346 I will refrain from it since everybody asks me to do so."

6347 The king let go off his pain, but only in great torment.

6348 He ordered that two wet nurses be found for his child

6349 Who night and day served her well.

6350 Until the age of seven, they took care of her in such a manner,

6351 They never again saw King Florent laugh,

6352 But [only] sigh for his wife night and day;

6353 He kissed the mouth and the chest of Yde.

6354 At the age of seven, she was instructed in reading: 
6355 She learned well, knew well how to read her Psalter

6356 And how to write in Romance and Latin.

6357 Indeed, anyone who is so well taught has a good heart.

6358 At age fourteen, she was such a beautiful maiden

6359 That everybody rejoiced at her beauty.

6360 Dukes and princes requested her from her father,

6361 Counts as well as kings would gladly take her,

6362 Not one came who was not turned away.

6363 They asked for her from beyond the province of Rome;

6364 The king answered that he did not want to marry her off,

6365 So that he would have her companionship for himself.

6366 He did not yet want to let go of her:

6367 She was his pleasure; he shall not take any other love.

6368 He hugged and kissed her often

6369 In the name of his wife whose daughter she was.

6370 One day in May, when the lark was calling

6371 The merlion was singing and the magpies enjoyed themselves

6372 One Sunday, after hearing mass,

6373 Florent and his entourage left the monastery -

6374 He had one hundred knights in his company.

6375 In a ancient orchard, 
6376 They were sitting on the verdant grass.

6377 The king spoke in front of his baronage:

6378 "Sires," he said, "So help me God,

6379 I have long been in this infirmity.

6380 Many years have passed, indeed fifteen,

6381 Since I have lost Clarisse, the queen,

6382 The beautiful lady whom Jesus may bless

6383 I truly cherished her in deep love;

6384 Never since have I had the company of a woman.

6385 Now it is right to tell all of you:

6386 My desire to have a woman has grown stronger;

6387 I will have one, there is no one who can refuse it to me."

6388 The king's men showed great joy

6389 That his thought was preoccupied with a woman:

6390 "Sir," they said "In the name of your great virtue

6391 From where will she come and from which country?

6392 So help us God, she will be fortunate

6393 To be declared queen of Aragon."

6394 And Florent said: “By my father's soul,

6395 Many noble men have asked for my daughter;

6396 I do not know any man to whom mine could be better wed: 
6397 Within one month, I will have married her:

6398 I will take her for the sake of her mother's love."

6399 Sorbarrés said: “What are you saying, scoundrel?

6400 Your daughter thus shall be married to you?

6401 With the law that God has given us,

6402 Your soul will be damned to hell."

6403 And Florent said: "Woe to him who thinks such a thing.

6404 If there is any man who blames me for it

6405 I will immediately have his soul severed from his body."

6406 He asked for his daughter and she was brought to him

6407 God, how she is radiant and full of color! -

6408 With a smile, she came before the king, her father,

6409 And the king seized her in his arms,

6410 He kissed and hugged her well ten times;

6411 And she submitted to him,

6412 But she did not know his desire nor his intention:

6413 If she finds out, she will be angry.

6414 She entered her dear father's heart so forcefully

6415 That she pierced his viscera:

6416 He will lose his mind if he cannot marry her.

6417 God, why does the king have such thoughts? 
6418 Because of which so many women will yet be wet with tears,

6419 And so much land will be destroyed and devastated,

6420 So many young people will lose their inheritance from it,

6421 So many a maiden proclaimed an orphan?

6422 The king will have for himself his dear saddened [woman].

6423 So much did he hug and kiss Yde

6424 [Until] the day passed [and] the evening approached.

6425 The king's people were anguished

6426 All that for Yde, with whom he had fallen in love.

6427 The matter was not told by anyone.

6428 They said to each other: "So much is clear:

6429 If he took her secretly into his chamber,

6430 She would never be delighted with Florent

6431 Unless he would immediately take her by force.

6432 If she knew the thoughts of his heart,

6433 She would rather flee beyond the frozen sea

6434 Than wait for him - so much is clear --,

6435 For the maiden is so well educated

6436 That she is entirely devoted to serving God."

6437 King Florent did not delay anything,

6438 So he asked for his people, he did no tarry any longer; 
6439 He took a letter and a deed, and sealed them:

6440 To the high barons in whom Florent confided

6441 He sent word everywhere, and the messenger went out

6442 To announce the king's wish to marry;

6443 Everybody heard it; they displayed great joy.

6444 They will want to know what he will ask them

6445 And the occasion for which he has summoned them.

6446 So many people entered Aragon

6447 That the market place and the town were crowded with them.

6448 The barons all dressed and adorned themselves,

6449 Then, they went to court - none of them was delayed.

6450 King Florent's heart was full of joy.

6451 Each of the high men greeted him most courteously;

6452 He hugged each of the high barons

6453 And told them that he wanted to hold a council

6454 About taking a wife, for he wished to do so.

6455 Several of them told him that he had waited too long:

6456 "Distinguished one, take a wife from whom honor will come to you:

6457 So help me [us] God, your court will want one very much.

6458 It was a loss when your wife passed away,

6459 For you will never find her equal." 
6460 The king heard them, and shook immediately his head.

6461 He ordered that they be washed and fed:

6462 There were plenty of dishes.

6463 They got up when the meal was finished;

6464 He assembled his council in his orchard.

6465 And Sorbarrés sat beside him,

6466 [And] the sentinel Guis, who had always been favorable towards him.

6467 "[In the name of] Florent, our good king," he said, "Listen now:

6468 You have spoken of marriage some time ago.

6469 Consider now where your heart will lead you

6470 And answer as you wish.

6471 There is no woman so worthy on this side of the sea.

$6472 \mathrm{He}$ [the king] wants to know that [such is settled].,26

6473 The king said that he would take his daughter,

6474 Not any other but her he would marry, he said.

6475 When they heard it, they nudged each other;

6476 They raise their hands: each of them crossed himself.

6477 "Sire," they said, "May God the Almighty keep you from doing it!

6478 Never has it happened, nor will it ever happen.

6479 There is no man, who, if he heard you,

\footnotetext{
${ }^{26}$ Translator's note: unintelligible sentence
} 
6480 Would not consider you a fool because of such a thing.

6481 Remember God, who gave us life,

6482 Who gave us baptism and faith.

6483 Let's hold up the law that he gave us:

6484 Whoever will act against it, will be damned.

6485 When he ordained marriage

6486 Jesus ordered every Christian

6487 Not to marry his own kin:

6488 You cannot have [do] it before the fourth degree,

6489 Or otherwise, it will be heresy.

6490 Florent heard it and got very angry over it;

6491 He said to his people: " Do not talk of such thing.

6492 So help me God, no other but me will have her;

6493 The damsel will stay with me."

6494 King Florent made them worry,

6495 He asked for his daughter and had her prepared.

6496 His noble counselors went there.

6497 And Sorbarrés began to try to change the king's mind.

6498 The maiden with the fair face adorned her body

6499 With golden clothes that were very precious.

6500 There were many knights escorting her. 
6501 She came out of the chambers, entered the grand palace.

6502 The entourage was turned in her direction;

6503 Her beauty moved all of them.

6504 I have to tell and declare it to you well:

6505 She was whiter than snow in February;

6506 In addition to the white, she had color that became her well -

6507 She was red like a rose on a rose bush -

6508 Her eyes were brighter than a moulting falcon's

6509 She had blond hair that curled in the back -

6510 In comparison, the beauty of golden threats was not worth a denier.

6511 Never is crystal to be compared

6512 Or whiter - I dare well attest to that -

6513 When Yde's forehead is brought together with it; ${ }^{27}$

6514 A slender nose, arched eye brows,

6515 Red lips and well-fashioned teeth,

6516 Her neck is whiter than the most precious ivory,

6517 She has delicate hands, straight fingers,

6518 Low hips and arched feet:

6519 So well is her body endowed with all that is good.

6520 She is a young woman of full fifteen years,

${ }^{27}$ The translation of lines $6511-13$ is taken from de Weever. 
6521 She has no breasts of which one takes any notice.

6522 She turned her body towards her father;

6523 The king hugged and kissed her gladly.

6524 She sat down beside him on an embroidered silk cloth

6525 And did not know of what he wanted to speak to her.

6526 "My beautiful daughter," Florent said, "Now listen:

6527 You are an orphan, and I have great pity for you.

6528 Since I have lost your mother, I have not been happy,

6529 But through you, my body has been filled with new joy:

6530 You resemble your mother's proud face more

6531 Than anything that has ever been under the sky;

6532 For your likeness to her, I hold your body most precious,

6533 And thus will take you as companion and wife."

6534 She heard it and bent forward her head.

6535 "Father," she said, "Are you mad?

6536 Do not speak of this anymore, for it is too big a sin!"

6537 Thereupon, the maiden wanted to get up.

6538 "Daughter," he said, "Do not speak of this.

6539 Truly, you will easily make me very mad."

6540 All his barons kneeled down

6541 And said: "King, have mercy on yourself. 
6542 You want to dishonor your daughter and your body."

6543 Florent said: "Be it an infidel, a villain

6544 There is no living man who could hold me back from her,

6545 Except for the one who was put on the cross.

6546 I will take her, no matter whom I have to destroy for it!"

6547 The king's daughter was deeply troubled;

6548 She cried all night and called herself a captive:

6549 "What will become of me? Why was I ever born?

6550 If my father lies with me,

6551 My soul will certainly be dammed from it.

6552 I will flee, I will not stay here.”

6553 Behold! There is the king and his big entourage,

6554 Who has his daughter brought into his chamber:

$6555 \mathrm{He}$ is afraid that she might be abducted from him.

6556 He draws a bath where his daughter will be bathed,

6557 So that she is terrified.

6558 Behold! There is Desiier de Pavie ${ }^{28}$

6559 He enters the town with many knights;

6560 Florent and his household go to meet him.

6561 And the maiden jumps out of the bath;

${ }^{28}$ Desiier de Pavie, uncle of Florent and brother of the wife of Garin (Florent's father) is an old adversary of the family who appeared in a previous episode. 
6562 She puts on men's clothing, she does not hesitate with anything:

6563 She disguises herself well as a man.

6564 She comes to the stable, dashes to a war horse,

6565 Then she mounts, for she does not tarry.

6566 By no one she is seen nor recognized.

6567 She goes out of Aragon. May God help her!

6568 Florent came back to his chamber and looked for her,

6569 He noticed very well that she had escaped.

6570 He became very sad - I do not lie to you [gap in manuscript]

6571 He suffered greatly for the maiden,

6572 And the people around him lamented and cried.

6573 They told the king: "You lost your war horse:

6574 Yde, your daughter, is escaping on it."

6575 There was a lot of grief in the town

6576 For the fair-faced Yde,

6577 Whom they had lost in such circumstances.

6578 And Yde went away in great haste;

6579 She wore men's clothing out of fear.

6580 When she saw that dawn approached,

6581 The beautiful one took refuge in the forest all day;

6582 She rode at night, so that there was no delay. 
6583 Within one month, she sold her arragon ${ }^{29}$

6584 She had nothing to live: She had no gold nor even a penny

6585 Now she went alone on foot without company.

6586 Her clothes disguised her well as a man:

6587 She had bought boots and a hooded cape;

6588 Linen breeches, none so nice could be seen [anywhere];

6589 She had a belted sword and wore a staff.

6590 She set off for Germany.

6591 So far she traveled that she came to Barsillon [Basel],

6592 But she did not understand their language at all.

6593 She took lodging in the town;

6594 She completely spent her money.

6595 She lodged until Rogation day [Gangetyde]

6596 When an army came full force to town:

6597 They lodged there for two weeks,

6598 They would wait there for the rest of their troops.

6599 They would go straight to Rome, to King Oton,

6600 Who had challenged a king 30

6601 Who held Castile and parts of Spain:

\footnotetext{
${ }^{29}$ Type of horse from the region

${ }^{30}$ The text refers here to the King of Spain to whom Olive, daughter of King Oton, was refused in marriage and whom Yde will fight later on to free the Roman kingdom.
} 
6602 These Germans would go against him.

6603 Yde the beautiful heard their speech,

6604 If she is capable of doing something, they will regret it.

6605 Yde the beautiful did not tarry:

6606 She thought highly of King Oton

6607 And, if it is in her power, he will have help from her.

6608 Gently, she got acquainted with the Germans,

6609 She showed herself often in their hostel.

6610 One friendly German called upon her:

6611 "To whom do you belong? Tell me, do not hide it."

6612 He said to Yde: "Handsome brother, now listen to this."

6613 "Sire," she said, "To whomever it will please;

6614 He will have my valuable service for two weeks.

6615 I served in Aragon a long time ago;

6616 The one who brought me here is now dead.

6617 I know well how to serve and, for whomever will take me,

6618 How to lead a pack horse;

6619 And if it so happens that we go to battle,

6620 I think that people will be afraid of me."

6621 The German said: "Much good will come to you.

6622 What is your name? Do not hide it from me." 
6623 "My name is Yde," that one answered.

6624 "Brother," he said, "You will lead my horse:

6625 I engage you into feudal service, nothing bad will come to you."

6626 Yde bowed to the German at once;

6627 The German led her to his hostel.

6628 May God, the king who created everything, protect Yde!

6629 She has been served, now she will serve.

6630 Now may God, who created the whole world, protect her!

6631 If she is found out, great pain will come from it.

6632 Three days later, such a big army assembled:

6633 They traveled swiftly towards the province of Rome.

6634 Lady Yde mounted a horse,

6635 She, who dressed herself well in the ways of a man.

6636 She served so well that everybody praised her.

6637 For a whole month, the army pressed on

6638 Until war and battle was near.

6639 They noticed a forest in a valley:

6640 There were yet fifteen great leagues [miles] ahead of them;

6641 There were more than seven thousand thieves:

6642 They were well armed, each one on a horse.

6643 They saw the Germans from the other side; 
6644 Each of them hurried to go plunder from them.

6645 One German, Goutehere, swore,

6646 [That] if they ran him over, he would defend himself.

6647 And Spaniards came from the bottom of the valley;

6648 They yelled at the Germans: "Hold still!

6649 You are all dead, none will escape from here,

6650 If you do not put down everything you own."

6651 Yde answered that she would not surrender it.

6652 She spurred on her horse in front of her master;

6653 She had no shield at all, but she fisted her lance.

6654 She struck a Spaniard whom she met

6655 So that his shield broke and shattered

6656 And from behind, she pierced off his armor;

6657 She forced the lance into his back,

6658 And struck him down: Never again will he get up.

6659 Yde the beautiful took back her lance,

6660 Never before on any day had she truck down a man:

6661 She knew little of arms; she turned around.

6662 One German behind her looked closely at her,

6663 And said to her: "Lucky the one who gave birth to you!"

6664 When the beautiful Yde had started the battle, 
6665 The Germans broke ranks

6666 During the clash, many a shield got pierced

6667 And many a suit of armor shattered and torn apart,

6668 Many a German was knocked down to the ground;

6669 Yde held the sword raised up;

6670 Whomever she caught up with, she dismounted quickly.

6671 Badly did both sides clash in battle:

6672 The Spaniards were full of rage;

6673 The Germans were well put to the test,

6674 Struck with arrows and thrown sickles,

6675 And although they were so well equipped,

6676 None of the Germans escaped

6677 Except through death.

6678 Yde escaped running on the rocky ground:

6679 She mounted a running horse;

6680 She had nothing but the sword - she lost her lance

6681 If she is afraid, nobody should be surprised,

6682 For she did not know the route nor the path.

6683 She had nothing with her that she could eat.

6684 At night, she lodged alongside a thicket

6685 Until the morning, when it started to become lit; 
6686 The whole day she rode her horse in front of her;

6687 Up into the night, when it started to become dark.

6688 Great hunger tormented her gentle body.

6689 On her right, she noticed beside her a rock;

6690 She caught sight of a fire close to it.

6691 Thirty thieves were sitting for dinner;

6692 The young lady turned her steed towards them.

6693 When the thieves saw her approach,

6694 They discussed her amongst each other.

6695 "Look," they said, "a lousy squire.

6696 He will abandon his steed to us, to whomever can [get it]."

6697 And the beautiful Yde started to yell:

6698 "May God, "she said, "Be with you for this meal.

6699 It seems to me that you are very comfortable.

6700 If it pleases you, welcome me in your circle;

6701 I will gladly pay for my share."

6702 And the thieves, who were insolent,

6703 Answered: "We have well discussed the matter.

6704 Is there a foot-soldier or a knight with you

6705 Who guides you through this vast forest?"

6706 The maiden said: "By faith, to my great misfortune, 
6707 There is no one with me, rest assured."

6708 One of the thieves grabbed her bridle

6709 And told her: "This one is captured.

6710 Let's take care of him before you eat,

6711 So that this vagabond may not escape you:

6712 None of us may be out-witted."

6713 The maiden said: "And why are you in such a hurry?

6714 You will have little gained by my death.

6715 I will gladly surrender to you:

6716 Take my sword and be appeased.

6717 I have such hunger that I am nearly mad;

6718 For the love of God, I ask you for food."

6719 The leader said: “Come forward, squire.

6720 So help me God, you will not be touched here.

6721 Rather I will give whatever you need."

6722 Yde answered: "You may have a hundred thanks for it."

6723 She sat down at the longed-for meal.

6724 The lady sat at the meal.

6725 Now may God protect her, the son of Saint Mary.

6726 She ate what she desired.

6727 And the thieves who cursed the ways of the Lord, 
6728 Gathered their [table] cloth after the meal.

6729 They quarreled and fought with each other

6730 Because of the squire who was still alive;

6731 Now they would kill him, they would not wait any longer.

6732 [But] one of them said: "We will not do this:

6733 The squire is full of courteousness;

6734 Since he has taken lodging with us,

6735 He will come steal with us in brotherhood,

6736 Or if not, he will lose his life."

6737 They went to Yde, and started talking to her:

6738 "What is your name? Tell it to us, dear sir."

6739 That one answered, full of fear to die:

6740 "My name is Yde and I am from Pont Elye.

6741 I was supposed to go straight to the province of Rome,

6742 But the ones from Spain killed my company.

6743 Help me, and you will act nobly,

6744 And give me back my Persian steed."

6745 The leader said: "It will not happen like this:

6746 You will be a thief for the rest of your life;

6747 With you, our group will be stronger,

6748 Or if not, your head will be cut off." 
6749 Yde answered: "That is not courteous.

6750 I will not get involved with robbery.

6751 Never has there been a thief in my family line,

6752 I would not know how to conduct myself in such work;

6753 But give me back my blazing sword

6754 And my steed - there is none like it as far as Russia.

6755 When I will mount it, may one of you challenge me:

6756 If I cannot defend myself, you [shall] kill me.

6757 You sell your lodging for too high a price,

6758 If you have my steed in your possession."

6759 The leader said: "You have a bold heart.

6760 It is necessary to fight me all-out:

6761 If you strike me down in this meadow,

6762 You will be slain by this company;

6763 And if you fall - I will not lie to you -

6764 You will not have any sword nor Nubian steed:

6765 These clothes will be seized from your back."

6766 The maiden said: "Be cursed who concedes to that!"

6767 Thus, she quickly stripped off her over-coat,

6768 All the thieves looked and laughed at her.

6769 But Yde is well raised. 
6770 She said to the thief: "Once you have sorted out this matter

6771 Have your company pull back from here

6772 And bring here my Nubian steed.

6773 And may my shining sword be in the saddlebow.

6774 For I heard an honest man be told once

6775 That only a foolish man confides in thieves."

6776 All of those who heard it, agreed to it.

6777 Thus they did as the beautiful one had planned.

6778 And she came to the fallen thief,

6779 She folded and fastened her arms around his waist,

6780 She raised him up fully [one and a half handbreadths]

6781 Then, she held him tight against her chest

6782 She pretended to bring him down to the left,

6783 [But] turned him to the other side and threw him down on his back.

6784 Lady Yde held quite courageously

6785 The strong, vile thief between her arms.

6786 She threw him to the ground so hard,

6787 Onto a boulder so miserably,

6788 That not a tooth remained in his mouth

6789 That did not hurt him miserably,

6790 And that his head split in two halves. 
6791 Yde had no wish to hold him any longer:

6792 She went to the steed, and mounted it without delay,

6793 She pulled the sword and cried out loud:

6794 "Sons of whores, stinking, bad thieves,

6795 Your treachery will not be worth anything to you.

6796 You had evil intentions towards me

6797 This one fought; I think that he regrets it.

6798 I am not afraid, even if there were more than a hundred of you."

6799 Then, she said quietly, so that nobody heard it:

6800 "I must have a lot of prowess and courage

6801 For I am the daughter of powerful King Florent."

6802 While she went away thinking in such a manner,

6803 One of the thieves seized her by the bridle.

6804 Yde saw him, lowered the naked sword,

6805 [And] cut his fist off at the wrist.

6806 And that one fled, expressing cries of pain.

6807 Yde went away, she did not tarry any longer,

6808 And the horse took her away so swiftly

6809 That she took off more quickly than their falling arrows.

6810 Now may God, to whom the world belongs, protect her!

6811 [Thus] many people escape great danger. 
6812 And so the beautiful with the noble body went away.

6813 She passed the forest, she did not rest at all;

6814 Anxiously, she approached Rome.

6815 She immediately entered the town;

6816 She did not stop until she reached the palace.

6817 On the foothill of the palace, she dismounted,

6818 Then, she climbed to where she asked for the master.

6819 She greeted the king quite courteously:

6820 "May God the almighty who lives in the firmament,

6821 Save the king that I see before me,

6822 And his barons and whoever belongs to him."

6823 The Romans and all others were silent;

6824 All of them listened to Yde.

6825 They all together thanked her

6826 Because she had spoken so wisely.

6827 The mighty king told her what he thought:

6828 "And may God save you," he said gladly.

6829 "Where are you from, my friend, and from which people,

6830 From which country and who are your parents,

6831 You who comes here all alone?"

6832 "Sire," Yde said, "You shall hear it at once: 
6833 I am a squire; I do not own a single acre of land.

6834 For a long time, I served in Germany:

6835 I was successful in battle, because of which many hearts betrayed me.

6836 I saw an army of people the other day

6837 Who, in truth, swore your death:

6838 They secretly went to the king of Spain;

6839 They lost a good half of their people,

6840 Whom I helped to deliver to pain.

6841 Now I come to you, spurring heavily.

6842 Receive me, if it pleases you,"

6843 The king heard her and looked at his people.

6844 The King of Rome looked at Yde,

6845 He saw very well how tall, muscular and well built he was;

6846 He cherished her speech greatly.

6847 Behold! There came the daughter of the crowned Oton:

6848 There was none so fair in the entire kingdom;

6849 Olive was her name; she was full of virtue.

6850 All the barons rose in her direction.

6851 As a token of friendship, she sat down beside Oton,

6852 And looked gently upon the squire.

6853 Oton shouted, full of pride; 
6854 He said to Yde: "Friend, now hear me:

6855 What are your name and your family line?"

6856 "Sire," she said, "They call me Yde

6857 Of Tarragon, because I have an aunt there.

6858 I am cousin to a powerful lineage:

6859 Count Aimmeris and Namles, the bearded one;

6860 I almost belong to Guillemer, the Scot,

6861 But I was banned because of my relatives of Hardré;

6862 Since then, I have endured much hardship."

6863 Oton said: "You will be of my lineage.

6864 I engage you into feudal service: I believe that there is great valor in you.

6865 Olive, daughter, have you listened?

6866 I engage this renowned squire for you.

6867 He will serve you at your will."

6868 "Sire," she said, "Five hundred thanks and gratitude.

6869 I do not have any other wish; it suits me so much."

6870 The Romans gave permission in great agreement,

6871 They looked upon Yde with great pleasure.

6872 The king called and addressed him:

6873 "My friend," he said, "Now you will serve me as suits me.

6874 I have a daughter of great beauty; 
6875 She will hold my land and my kingdom.

6876 Now watch out well how you behave yourself:

6877 If you serve her well, you will fare well."

6878 "Gladly, Sire," said Yde;

6879 "I will do so, Sire, "said Yde,

6880 "So that everybody will be thankful to me."

6881 "What are your skills?" said King Oton.

6882 "Sire, " she said, "Whatever one can command:

6883 Above all, I know well how to pray to Christ

6884 And to bring great honor to an honest man,

6885 To give of my possessions to the poor

6886 And to defeat the haughty with my strategic words

6887 And to draw near to me the honest man;

6888 To carry a banner earnestly

6889 And, if it comes to assemble for battle,

6890 There, you shall fear me.

6891 I know well how to employ and give a blow;

6892 If I have been wronged, I know well how to shake it off.

6893 And how to hide my anger in my heart;

6894 And I also know well how to stable my horse

6895 And how to comb and lead it to the water well; 
6896 I know well how to serve dinner at the table."

6897 "So help me God, " King Oton said,

6898 "If there is so much valor and virtue in you

6899 As I hear you here describe,

6900 One must serve and honor you well,

6901 Hold you dear and love you in high court.

6902 I am happy that you entered this place;

6903 I wish that you never leave me."

6904 Yde heard and bowed to him.

6905 From then on, Yde stayed with Oton,

6906 The noble king of Rome praised her.

6907 She was conscious of serving well every day.

6908 She worked so hard night and day

6909 That her services pleased everybody.

6910 Olive looked upon her with pleasure.

6911 And Yde prayed to the holy Virgin

6912 That she may protect her so that she would not be found out,

6913 In which case, she would be condemned to die.

6914 She brought honor to the poor,

6915 She gave much alms in God's honor.

6916 When the opportunity presented itself, she went to the monastery: 
6917 She often prayed for King Florent, her father,

6918 Because of whom she was so dirty and stained,

6919 Because of whom she fled from Aragon:

6920 Indeed, the king engendered her with his flesh.

6921 An entire month she stayed like this

6922 In Rome, the praised, mighty city -

6923 She was distinguished and strong and well formed.

6924 The fair one stayed in the palace.

6925 Behold! There came a messenger with great speed;

6926 He told his news in front of the king:

6927 "Hear me, " he said, "just emperor:

6928 The King of Spain has set fire to your land;

6929 And his troops penetrated your country so far,

6930 That they are assembled just below Rome:

6931 They have cut off many a Roman's head.

6932 The King of Spain swore to them his oath:

6933 Before two weeks will have passed,

6934 He will have quartered by force this big tower

6935 And violated your daughter by force;

6936 And he will have cut off your own head

6937 For your daughter who was refused to him. 
6938 It would have been better if he had married her

6939 Instead of having so many people die and pass away for it.

6940 King, go against him and defend your country,

6941 Or if not, your town will be destroyed."

6942 When Oton, the emperor heard this,

6943 He asked for Yde without further delay

6944 And then, he told him in secret:

6945 "Eh! Noble Yde, and what are your thoughts on this?

6946 Advise me on this betrayal.

6947 No man has ever asked me for war

6948 Who has devastated and laid waste to my land."

6949 "So help me God, Sire, " Yde said,

6950 "I will go see them wearing arms:

6951 Give me some people to go give them battle."

6952 Oton responded: "I am pleased with what I hear."

6953 Quickly, he sounded his bugles;

6954 Ten thousand Romans heard it and armed themselves quickly;

6955 They came and presented themselves in front of the king immediately:

6956 "Sire," they said, "What is your wish?

6957 We are ready for whatever pleases you."

6958 "Sir barons," said Oton, the emperor, 
6959 "To you I lament about these enraged people

6960 Who attacked my land near Rome.

6961 Look at Yde who is the leader of the army.

6962 Go with him, Ybert, into the great valley,

6963 And watch out that there may be no betrayal.

6964 Help him, with all your slashing swords,

6965 Anyone who shall not do so, by my father's soul,

6966 On your return I will give such pay

6967 That the head above his shoulders will be cut off."

6968 Yde went away with a noble company.

6969 She left Rome, the ancient strong city;

6970 As far as the Tiber, she did not rein in her horse

6971 And the Spanish made a lot of noise,

6972 For they believed to have laid siege to the town.

6973 For now, the troupes were besieged,

6974 But the matter will be decided differently.

6975 Yde came ready for battle;

6976 She called upon God, the son of Holy Mary

6977 She bent forward her face, in a green helmet.

6978 And she pressed her shield against her chest. 
6979 The fair one was directed towards Embronchart; ${ }^{31}$

6980 She led her big company to Mount Caillet;

6981 Foolish was the king who had great feudal power.

6982 He raised his banner towards Yde,

6983 And the fair one approached him.

6984 She struck Embronchart on his beautiful shield,

6985 So hard that she pierced and broke it,

6986 And she shattered and tore apart his coat of mail;

6987 She pierced her lance through his body.

6988 He fell off his noble steed, dead and stretched out.

6989 She saw him fall and then began to address him:

6990 "Away, treacherous one! May the body of Christ damn you!

6991 Alas for you that you came here: You have started such thing

6992 From which more than a thousand will lose their lives.

6993 I demand the plains of Rome from you."

6994 Then, the slender maiden said quietly:

6995 "True God, save this tired captive,

6996 Who for honor changed into a man!

6997 To avoid sin, I escaped to this place

6998 And left my father and his land.

${ }^{31}$ Nephew of the King of Spain 
6999 Now look after me, sweet Virgin Mary.”

7000 At these words, she drew her sword,

7001 She cut off the head of Pierron de Bus

7002 And more than seven others she delivered to such torment,

7003 Heading forward, she went and took one after the other:

7004 She did not want to distinguish the good from the bad.

7005 The Spanish were delivered to a massacre;

7006 They (the Romans) escaped and turned away to a pine grove,

7007 Where they met Gualerant d'Aubespine,

7008 Together with him, they were more than three thousand knights.

7009 The rest began the roar and din of battle:

7010 In that very place, there were so many jousts

7011 And so many heads of the Spanish were cut off,

7012 That they fled, their men defeated.

7013 Alars of Grong shouted loudly at them:

7014 "By Saint Fagon, this matter is decided badly:

7015 Misfortune led us to invade like this.

7016 Here reigns this fair one with the unbroken shield

7017 With the cross that shines and blazes so.

7018 If I had known that there was such a baron in Rome,

7019 I would have never entered it in all my life. 
7020 With his body alone, he delivered battle,

7021 And they [all] rely on the valiant acts of this baron.

7022 The ones of Rome have great possessions:

7023 They will receive all these pavilions and tents."

7024 Yde was well looked upon and noticed,

7025 For Olive saw her from the battlements.

7026 Her body trembled all over with joy,

7027 She said quietly so that nobody could hear her:

7028 "He will be my friend. As soon as tomorrow, I want to tell him.

7029 Never before have I been so taken by a man,

7030 It is sensible and right to tell him."

7031 Upon these words, the baronage returned.

7032 They admitted the whole truth to the king.

7033 How he [Yde] decided the battle,

7034 How he sliced everyone with his polished sword:

7035 There was no baron like him as far as the Greek sea.

7036 When King Oton heard the truth

7037 That he had such a noble man in his vassal Yde -

7038 [That] he freed him from the Spanish so well -

7039 The powerful crowned king was full of joy.

7040 He brought great honor to Yde: 
7041 Within one year, he put him to the test so well,

7042 That he freed the entire country:

7043 He killed the ones and drowned the others

7044 And he brought so many to prison

7045 That he freed the land and the kingdom.

7046 The king's daughter loved him so much

7047 That she told him - She could not hide it any longer from him.

7048 One day, King Oton called an assembly

7049 He asked for the fathers and the mighty ones of Rome

7050 "Barons," he said, "Now hear my thoughts:

7051 I have a daughter who receives much praise.

7052 Before I die, I would like to marry her,

7053 If I give her to my knight Yde;

7054 He shall have Rome together with my reign,

7055 For I do not know any baron such as Yde."

7056 The Romans agreed with pleasure;

7057 Upon which they hugged him in deep friendship.

7058 King Oton said: "Now listen to me, Yde:

7059 You have freed my entire country for me;

7060 I want to give you here the reward:

7061 I have a daughter of great beauty: 
7062 You will have her as wife and companion

7063 And my kingdom, when I passed away."

7064 "Thank you, good king, in the name of God in majesty.

7065 I do not possess more than a nickel in this world:

7066 It will be unjust if you have not considered well

7067 To whom you give your child in marriage.

7068 I am a poor man, I do not want to marry

7069 On the contrary, I need to ask for wages."

7070 "What?" Oton says. "And what do you imagine?

7071 You thus refuse my child

7072 And the land that I have offered to you?"

7073 "No, sire, in the name of God," Yde said,

7074 "On the contrary, I will take her with pleasure and gratitude

7075 If it pleases and suits her.

7076 Send for the maiden immediately."

7077 And she came to them, she did not tarry.

7078 Now Oton, the crowned, called upon her:

7079 "My fair daughter," the king said to her, "Listen:

7080 It is the proper thing for you to promise henceforward

7081 That you will act according to my will

7082 And that you will lead my reign after me. 
7083 Once I am dead, you do not have any protector:

7084 All my barons have judged in favor

7085 That you will take my knight Yde,

7086 And he will be king of this kingdom."

7087 The maiden said: "I now have what I want.

7088 I have not wasted my time in this life

7089 As I will have what I desired so much."

7090 She kneeled down at her father's feet;

7091 As she got up, she shouted loudly:

7092 "Father, "she said, "Now think of hurrying up:

7093 Every day, it seems to me that he shall have to leave."

7094 When the barons heard the fair one,

7095 They all together displayed great joy.

7096 Then, the king said: "Come forward, Yde,

7097 If you pledge yourself to my daughter in loyalty;

7098 I will give her to you with my kingdom.

7099 On this day, I remember well your service,

7100 That you have freed my land;

7101 Now you shall be greatly rewarded."

7102 Yde heard him and her blood froze.

7103 She did not know how to act; 
7104 She did not have any member with which she could copulate.

7105 Many times, she called upon our Lord:

7106 "Glorious Lord, who resides in the trinity,

7107 Take pity on this wretched body,

7108 That is forced to marry by necessity.

7109 Hey! Florent, father, what terrible thoughts you had

7110 That you did not want to give me to any baron,

7111 Rather you thought of taking me as your wife:

7112 Better to have let me burn in a fire!

7113 To escape the shame, I fled

7114 From your land because of your mortal sin.

7115 My body has been subject to much danger since.

7116 So I thought to keep safe in Rome,

7117 But it is clear that my body will be revealed.

7118 The king's daughter fell in love with my body;

7119 Now I do not know how to escape:

7120 If I tell them that I am in truth a woman,

7121 They will have killed and decapitated me immediately,

7122 Or they will tell the truth to my father:

7123 He will have me back immediately if he knows that I am here.

7124 In which case it will be necessary to flee beyond the sea. 
7125 However one looks at it, I am entangled in a bad affair;

7126 And in any case, I have deceived.

7127 Since I won over Rome and honor,

7128 I will marry the daughter of the crowned one,

7129 And may God do with me as he wishes."

7130 Thus, she said to the king: "I will do as suits you."

7131 They went straight to the monastery Saint Pierre.

7132 Yde wept; the people displayed great joy:

7133 Some young men were jousting in arms,

7134 The maidens cavorted and danced in rounds:

7135 The feast lasted for one entire month.

7136 The time approached that they should marry.

7137 There was a great abundance of knights;

7138 They wished to see Yde.

7139 One day, they went straight to the monastery.

7140 The Romans accompanied Olive with the fair face;

7141 Yde was in front; she let out great sighs;

7142 They did not stop until they reached the monastery.

7143 That day, they had her marry the maiden,

7144 She took Olive as wife and companion.

7145 Now the king had given a wife to his daughter, 
7146 For he thought that Yde was a man.

7147 They put on many rich brocaded cloths,

7148 Many silk cloths and coats trimmed with fur.

7149 They gave a meal in the great palace.

7150 The jongleurs rejoiced greatly:

7151 One could see harps and viols play,

7152 Ladies, maidens danced in rounds,

7153 And the young men behaved courteously.

7154 After the meal, when they had eaten,

7155 Each one returned to his house.

7156 There was great joy in the paved [great] hall.

7157 Many candles were lit,

7158 The whole town seemed to be in flames:

7159 People were adorned according to the custom of their land.

7160 After they ate, they took away the big table.

7161 They led Olive into the paved chamber;

7162 They brought her to bed and laid her down.

7163 Behold! There came Yde, wet with tears.

7164 She closed and bolted the chamber tightly,

7165 Then she went to the bed where her wife was,

7166 And she called her quietly in secrecy: 
7167 "My sweet friend and loyal wife,

7168 Tonight, the wedding night shall be given to you.

7169 I will have you with much distress although I long for you:

7170 For I have an illness which troubles me deeply."

7171 Upon these words, she hugged Olive.

7172 That one answered in a well advised manner:

7173 "Beautiful, sweet friend, we are alone here,

7174 And you are the thing that I have most desired

7175 Because of the goodness that I have found in you.

7176 Do not believe that I intend

7177 To play with raised paws.

7178 I was never disposed to such thing,

7179 But you shall abstain from me for two weeks

7180 Until the guests leave from here.

7181 So that I may not be derided and mocked for it,

7182 We will easily have found our sexual pleasures again.

7183 You have such virtue in your body

7184 That, please, do spare me.

7185 Aside from kissing, I would like very much to be hugged,

7186 But of the love that is private

7187 I ask of you that I be spared." 
7188 Yde answered: "Noble, honorable lady,

7189 I grant you whatever pleases you."

7190 Thus, they kissed and hugged each other;

7191 In that night, there was neither cry nor skirmish.

7192 The night passed, and the day returned.

7193 In the morning, the beautiful one got up

7194 And dressed and decorated herself richly,

7195 And the queen followed her.

7196 Oton looked at her closely in the morning

7197 If she was much changed and altered at all.

7198 "Daughter," he said, "How is the married life?"

7199 "Sire," she said, "Just as I like it."

7200 Thereupon, there was a burst of laughter.

7201 Olive was richly welcomed;

7202 The feast lasted eight full days.

7203 They [the guests] left for their country

7204 When the entire two weeks had passed.

7205 And Yde lay with his/her wife,

7206 She did not speak to her more than usual

7207 Did not touch her at all below her waist.

7208 [Yet] Olive had strong doubts, 
7209 She pulled and pushed her company

7210 And Yde knew very well what she longed for;

7211 She turned to her, she could no longer hide it from her,

7212 And told her the story from beginning to end

7213 That she was a woman -- she cried to her for mercy -

7214 And that she fled because of her father

7215 Away from his place through unknown lands.

7216 Olive heard it and was terrified by it.

7217 She consoled Yde most softly

7218 And she swore to her by the honored Virgin

7219 That she would never tell it to King Oton, her father,

7220 "[In the name of] my lord, who gave me to you;

7221 Henceforth you shall be completely reassured:

7222 For you are protected in loyalty,

7223 I will take my destiny together with you."

7224 [But] a servant heard their conversation;

7225 He swore to God that tomorrow, she would be accused

7226 And that Yde would have her soul ripped out of her body.

7227 The night passed, and the morning came.

7228 The ladies got up in the morning.

7229 And the servant - grief to the soul of his father! - 
7230 Went to the king in the great [paved] hall,

7231 And told him the story

7232 That Yde was a woman, to whom he gave his daughter

7233 And the province of Rome and his land.

7234 The king heard it and changed color;

7235 He said to the servant: "By the holy honored Virgin,

7236 What did you say, scoundrel, miserable traitor, thief?

7237 If this is not the truth, your head shall be cut off."

7238 "Sire," he said, "it is the proven truth.

7239 Make sure that she will be put to the test for you."

7240 The king wept, he lowered his face;

7241 Then, he thought about how he could test her.

7242 He had a bath drawn in the great hall;

7243 He entered it, then he called for Yde,

7244 And she came as the king had asked for her.

7245 "Undress yourself without delay:

7246 Come and take a bath with me; it is my wish."

7247 She responded, terrified:

7248 "Noble sir, King," said Yde with her shapely body,

7249 "Please, spare me this."

7250 The king responded: "You shall remove all your clothes: 
7251 If it is as I was advised,

7252 I will have the two of you burn."

7253 Yde trembled, Olive sighed:

7254 She cried for God's mercy on her knees.

7255 The king asked for his baronage,

7256 He told the whole story in front of all of them;

7257 Weeping, he cried out to them:

7258 "Sirs," he said, "What advice shall you give me?"

7259 "Have them burn," each of them cried to him.

7260 Just as Yde trembled of fear,

7261 A light descended from Heaven:

7262 It was an angel, God had sent him down.

7263 He said to King Oton: "Be quiet.

7264 Jesus asks you, king of majesty,

7265 That you bathe yourself and let this be,

7266 For I tell you in good truth,

7267 You have a good knight in this vassal Yde:

7268 God sends and gives him in his goodness

7269 All that constitutes a man's humanity.

7270 Let the servant go," the angel said.

7271 "He told you the truth, but that lies in the past: 
7272 This morning, she was a woman; henceforth, he shall be an incarnated man.

7273 God has power and might over everything.

7274 Oton, good king, you will come within eight days

7275 Into another life, you will leave this one,

7276 And will leave your daughter with Yde:

7277 They will have a son, he will be called Croissant;

7278 With his wit, he will bring a lot of goodness

7279 To many people by whom he will be little loved

7280 And he will be in great misery."

7281 Upon these words, the angel returned

7282 Who consoled the ones in Rome well,

7283 And on that day, Croissant was conceived.

Here ends the episode of Yde et Olive. 